\title{
Klassiõpetajate arusaamad õppiva organisatsiooni juhtimise distsipliinidest
}

\author{
Krista Uibu ${ }^{\text {al }}$, Merike Kaseorg ${ }^{\mathrm{b}}$, Toomas Kink ${ }^{\mathrm{c}}$ \\ a Tartu Ülikooli haridusteaduste instituut \\ b Tartu Ülikooli majandusteaduskond \\ c Tartu Raatuse kool
}

\begin{abstract}
Annotatsioon
Organisatsiooni kui terviku juhtimise seisukohalt on oluline, et iga õpetaja oskaks hinnata oma arenguvajadusi ja -võimalusi, probleeme lahendada ning meeskonnas töötada. Uurimuse eesmärk on välja selgitada, millised õppiva organisatsiooni juhtimise distsipliinide põhimõtted domineerivad klassiõpetajate arusaamades, ning arendada välja tõhusalt toimiva haridusasutuse juhtimise mudel indiviidi ja organisatsiooni tasandil. Toetudes Senge (1990) õppiva organisatsiooni juhtimise viiele distsipliinile, analüüsitakse artiklis põhikooli esimese kooliastme õpetajate mõttemudeleid ja süsteemse mõtlemise oskust, arusaamu isiklikust meisterlikkusest, ühisest visioonist ning meeskondlikust õppimisest. Uuringu valimi moodustab 47 kolmanda klassi õpetajat, kelle arusaamu ja hinnanguid uuritakse struktureeritud intervjuudega. Andmete analüüsimisel kasutatud muutuja- ja indiviidikesksed analüüsid võimaldavad leida erinevusi nii rühma keskmiste tulemuste tasemel kui ka eri profiiliga õpetajate rühmades. Uurimistulemustest selgub, et klassiõpetajad kirjeldavad põhjalikumalt õppiva organisatsiooni indiviidi tasandi distsipliine, seevastu organisatsiooni tasandi distsipliinide kirjeldused on pinnapealsemad. Tulemustele tuginedes saab arendada välja tõhusa haridusasutuse juhtimise mudeli.
\end{abstract}

Võtmesõnad: õppiv organisatsioon, juhtimise distsipliinid, õpetaja profiil, suunatud teemaanalüüs

\section{Sissejuhatus}

Organisatsioonijuhtimine kätkeb jätkusuutlikku arengut soodustavaid ning erinevate ressursside (sh finants- ja inimressursside) tõhusa

1 Haridusteaduste instituut, Tartu Ülikool, Salme 1a, 50103 Tartu; krista.uibu@ut.ee 
kasutamisega seotud otsuseid. Otsuste vastuvõtmine eeldab üksikute töötajate, meeskonna ja organisatsiooni kui terviku arengut ning uute teadmiste ja oskuste omandamist (Siimon \& Vadi, 1999). Mitmed autorid (DiBella, 1995; Kets de Vries, 2002) rõhutavad, et organisatsiooni juhi ülesanne on luua töötajate õppimist toetavad tingimused. Organisatsioonide arendamise üheks võimaluseks on õppiva organisatsiooni kontseptsiooni rakendamine (Ahonen \& Kaseorg, 2007). Sellel käsitlusel puudub küll ühtne määratlus, kuid põhilise ideena saab välja tuua keskendumise õppimisprotsessi kvaliteeti tagavate tegevuste arendamisele (vt Garvin, 1993; Nikkanen \& Lyytinen, 2005; Pedler, Bourgoyne, \& Boydell, 1991; Senge, 1990).

Õppiva organisatsiooni kujunemine haridussüsteemis on tihedas seoses juhtimisega (Killion \& Roy, 2009). Senge (1990) määratleb õppivat organisatsiooni kui organisatsiooni, kus inimesed suurendavad pidevalt oma võimet luua soovitud tulemusi ning kus toetatakse uut mõtteviisi, ollakse avatud ühistele püüdlustele ja arendatakse koos õppimist. Õppiva organisatsiooni mõistet on defineerinud ka Senge teooria edasiarendajad, kes ei ole kahandanud algdefinitsiooni väärtust, kuid on eristanud õppivad organisatsioonid mitteõppivatest, st õppiv organisatsioon edendab kõigi oma liikmete õppimist ning kujundab teadlikult ümber iseennast ja oma konteksti (Pedler et al., 1991). Selline mõtteviis on tihedalt seotud õpetajate igapäevategevustega õpilaste juhtimisel. Kui traditsiooniline õppimine seisneb teadmiste ja oskuste arendamises, siis Senge õppiva organisatsiooni idee sisaldab arusaamist, et töötajad on osa laiemast kontekstist. Õppivas organisatsioonis arendatakse komplekssemaid mõtlemismudeleid, seal valitseb kollektiivne püüdlus ja inimesed õpivad, kuidas ühiselt õppida. Tõhusalt toimivas haridusasutuses tegeldakse eelmainitud tegevustega järjepidevalt. Juhtimismudel kujuneb välja nende tegevuste organiseeritud toime koosmõjus ja seda võib käsitleda efektiivselt toimiva mikrokliima kujundajana. Inimressursside juhtimine haridusasutuses mõjutab muu hulgas õpetaja pädevust lahendada probleeme õppeprotsessis (DarlingHammond, 2000; Fullan, Galluzzo, Morris, \& Watson, 1998; Marinah \& Omar, 2004). See seostub nii õpilaste õpitulemuste kui ka hariduse tulemuslikkusega tervikuna (Sanders \& Rivers, 1996; Wenglinsky, 2002).

Haridust ei tule vaadelda kui süsteemi, vaid kui organismi, mis peab olema kohanemisvõimeline, loominguline ning vahendama kogemusi alt üles võrgustike abil. Praeguse uurimuse eesmärk on välja selgitada, millised õppiva organisatsiooni juhtimise distsipliinide põhimõtted domineerivad õpetajate arusaamades, ning arendada välja tõhusalt toimiva haridusasutuse juhtimise mudel. 


\section{Peter Senge õppiva organisatsiooni käsitluse rakendamine haridusasutuse juhtimises}

Senge (1990) nimetab distsipliiniks teooria ja tehnikate kogumit, mida peab õppima tundma ja kasutama, et suurendada kompetentsust nii konkreetses distsipliinis kui ka tervikus. Õppiva organisatsiooni põhine juhtimine lähtub viiest distsipliinist, milleks on isiklik meisterlikkus, mõttemudelid, ühine visioon, meeskondlik õppimine ja süsteemne mõtlemine (vt joonis 1). Seejuures võib iga distsipliin sisaldada erinevaid aladistsipliine (Torokoff, 2008), kuid teooria võtmeks võib pidada süsteemset mõtlemist (Kiedrowski, 2006). Senge oma kolleegidega (2003) lisab, et kõiki distsipliine korraga rakendada ei ole võimalik - neid tuleb rakendada omavahel seostatuna ja üksteisele järgnevatena, lähtudes konkreetsele organisatsioonile sobivast järjekorrast.

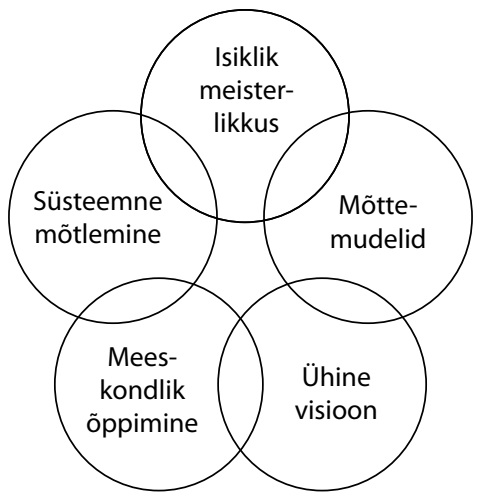

Joonis 1. Senge õppiva organisatsiooni distsipliinid

Fookuse järgi on võimalik jagada nimetatud distsipliinid kahte kategooriasse: individuaalseteks ja meeskondlikeks distsipliinideks. Esimene neist hõlmab isiklikku meisterlikkust, mõttemudeleid ja süsteemset mõtlemist, mis keskenduvad indiviidide käitumisele ja tegevusele organisatsioonis. Teine haarab organisatsiooni fookust: ühist visiooni ja meeskondlikku õppimist (vt Senge, 1990). Süsteemse mõtlemise võib tinglikult paigutada ka teise kategooriasse. Seetõttu eeldab juhtimisotsuste tegemine organisatsioonis koostööd eri tasandite vahel (Roots, 2004). Ahonen ja Kaseorg (2007) toovad välja, et siduvaks elemendiks organisatsiooni ja indiviidi tasandi vahel on läbipaistev kommunikatsioon ja toimingud, mis võimaldavad organisatsiooni töötajatel olla vajalikul määral informeeritud, avaldada mõtteid toimuva kohta ja saada sobival viisil tagasisidet. 


\section{Isiklik meisterlikkus}

Isikliku meisterlikkuse põhimõtted õpetavad nägema valikuvõimalusi ja vastutama tehtud valikute eest. Senge (1990) järgi on isikliku meisterlikkuse võtmeks indiviidi visioon ja arusaamad organisatsiooni kontekstis. See hõlmab eelkõige süsteemset mõtlemist, intelligentsust ja suhtlemisoskust ning aitab panustada ametialasesse edukusse (Anderson et al., 2006). Isikliku meisterlikkuse saavutanud inimene on arendanud endas võimet adekvaatselt tajuda hetkeolukorda (isegi siis, kui see on ebamugav) ja keskenduda samas oma isiklikule kuvandile (isegi siis, kui see tundub võimatu). See mõjutab muu hulgas õpetaja teadmisi, oskusi ja tegevusi õppeprotsessis (Darling-Hammond, 2000; Marinah \& Omar, 2004).

Õpetamine on personaalne tegevus, kus õpetaja realiseerib oma pedagoogilised arusaamad õppekavast, õpetamisest ning õpitulemuste hindamisest (Harrison, 2013). Åkerlind (2003) kirjeldab õpetamist kui info edastamist ja heade suhete loomist (olulised on nii õppijate rahulolu kui ka sisu edastamine) ning õppijate õppimise toetamist. Samas ei pruugi õpetajad teadvustada, millistele arusaamadele ja uskumustele toetub nende professionaalne praktika (Eley, 2006; Karm \& Remmik, 2013). On teada, et kogemused muudavad õpetaja arusaamu professionaalse arengu eri etappidel (Lampert, 1997; Torff \& Sessions, 2005) ning muutused võivad olla kahesuunalised: õpetaja võib muuta oma tegevust vastavalt arusaamadele ning arusaamad võivad kujuneda ja kinnistuda praktilise tegevuse tulemusena (Guskey, 2002).

Samas ei piirduta tänapäevastes õpetaja kutseoskuste käsitlustes ainult tunnis toimuvaga, vaid rõhutatakse õpetaja ametialase arengu tähtsust kooli kui organisatsiooni kontekstis (Loogma, Ruus, Talts, \& PoomValickis, 2009; Schults, 2012). Ametirollile lisaks oodatakse õpetajalt teiste rollide ja kohustuste täitmist, näiteks peab õpetaja olema ühtaegu õppekava arendaja, teadlane ja meeskonna juht (Cheng \& Tsui, 1999), kuid see omakorda võimaldab arendada uusi oskusi ja kohaneda keskkonna muutustega (Allen, 1996). Seejuures on väga oluline välja selgitada õpetaja arusaamad isiklikust meisterlikkusest, sest need on aluseks organisatsiooni ühise visiooni väljatöötamisele (Senge, 1990).

\section{Mõttemudelid}

Organisatsiooni edukus sõltub selle liikmete mõttemudelitest, otsustest ja käitumisest (Mumford, 1992). Mõttemudelid mõjutavad otseselt seda, mida ja kuidas inimene teeb - need on kujundid, kogemused ja arusaamad mälus ning alateadvuses (Võgotski, 2014). Isiklike mõttemudelite teadvustamine 
ja uurimine annab võimaluse neid muuta, tegeldes samal ajal sügavamate uskumuste (enesetõhususe, erialaste teadmiste ja organisatsioonikultuuri mõjude) uurimisega (Khader, 2012). Uskumuste ja mõttemudelite väljaselgitamine on keeruline just nende komplekssuse tõttu (Guskey, 2002; Pajares, 1992). On leitud, et inimese uskumused ja väärtushinnangud mõjutavad tema töist käitumist enam kui teadmised ja oskused (Meglino \& Ravlin, 1998).

Ôpetajatel, kelle isiklik meisterlikkus on suurem, on resistentsemad mõttemudelid, st professionaalsed oskused muudavad töötajad enesekindlamaks ja avaldavad mõju alternatiivsele mõtlemisele (Guskey, 2002). Samas on meeskondliku õppimise seisukohalt oluline väljendada oma vaateid ja arvamusi, mõista teiste omi ning põhjendada tehtud otsuseid. Et hinnata otsuseid kõrvalseisja pilguga, sobib kasutada tegevuste ja mõtete peegeldamist (Korthagen \& Vasalos, 2005), mis suurendab töötaja võimet suunata oma professionaalset arengut. Senge (1990) hinnangul on oluline tegelda organisatsioonis ka nende probleemidega, mis $\mathrm{nn}$ iseeneslikult esile kerkivad ja millele lahenduste otsimine arendab töötajate individuaalseid mõttemudeleid ja süsteemset mõtlemist.

\section{Ühine visioon}

Organisatsiooni tervikliku arendamise aluseks on ühine visioon, mille suunas liigutakse ning mille nimel muutusi ellu viiakse (Nikkanen \& Lyytinen, 2005). Scholtes (1998) leiab, et esialgse visiooni peaksid esitama organisatsiooni juhid, seejärel tuleb kujundada ühine visioon läbirääkimiste teel (Appelbaum \& Goransson, 1997; Senge, 2006; Senge et al., 2012). See eeldab, et kõigil töötajatel on olemas isiklik visioon oma tegevustest, millest leitakse ühisosa - see võimaldab töötajatel näha ühist teed ning tegevuspõhimõtteid, mis aitavad muuta visiooni tõelisuseks (Elenurm, 2004; Schults, 2012). Ühisele visioonile tuginevad ühiselt seatud eesmärgid (Senge et al., 2012), mille põhjal kujundatakse ühised väärtushinnangud (Griego, Geroy, \& Wright, 2000).

Kooli muutunud roll ja ülesanded esitavad õpetajatele uusi nõudmisi (Loogma et al., 2009). Õpetajatelt oodatakse enesetäiendamist, alustades vajadusest uuendada teadmisi õppeaine sisust ja õppekavas tehtud muudatustest ning lõpetades õppemetoodikat käsitlevate ja õpetaja enesetõhusust suurendavate koolitusteni. Nõudlus rakendada terviklikku ja integreeritud käsitlusviisi koolitustes ning ühistes ettevõtmistes on kasvanud. Selline käsitlusviis toetab ja arendab õpetajaid kogu karjääri vältel: õpetajad vajavad oma kompetentsi arendamiseks ja töö tõhustamiseks praktilisi 
näpunäiteid ning teavet uute arengusuundade kohta (Saadoja, 2013). OECD rahvusvahelisest õpetamise ja õppimise uuringust TALIS selgus, et Eesti õpetajad on enesetäiendamises osalemise määra poolest 23 riigi õpetajate arvestuses 7. kohal (Loogma et al., 2009). Kuigi väga suur osa õpetajaskonnast (93\%) osaleb regulaarselt enesearengut toetavates tegevustes, on Eesti õpetajate enesetäiendamise intensiivsus väike. $48,7 \%$ õpetajatest sooviks kulutada enesetäiendamisele rohkem aega (ibid.). Osalus pikemates ja koostööd eeldavates enesetäienduse vormides (nt koostöövõrgustikud, mentorlus) toetab õpetajate professionaalset arengut.

Ühise visiooni oluline tunnus on ka see, et töötajad õpivad vabatahtlikult, mitte seetõttu, et nad on sunnitud õppima. Kui ühine visioon puudub, siis ei aita organisatsiooni õppimisele kaasa ka üksikute töötajate tegutsemine (Kim, 1993). Senge (2006) sõnul on ühine visioon esimene samm, mis võimaldab inimestel alustada koos töötamist, isegi kui nad ei usalda üksteist. Ühine tulevikuvaade aitab liikuda meeskondliku koostöö suunas (Schults, 2012). Selle kaudu saadakse väärtuslikku tagasisidet kolleegidelt, kuid see omakorda suurendab ópetajate enesekindlust, nt uute õpetamisviiside rakendamisel.

\section{Meeskondlik õppimine}

Kooli kujunemine õppivaks organisatsiooniks kuulub juhi vastutusalasse. Juhi ülesanne on hoida organisatsiooni eesmärgid ja visioon nähtaval ning osutada meeskonna tugevatele külgedele, pädevustele ja arenguvajadustele (Nikkanen \& Lyytinen, 2005; Pont, Nusche, \& Moorman, 2009). Õppiva kooli valmisolek muutusteks eeldab juhtkonna õigeid otsuseid ja töötajate valmisolekut meeskondlikeks aruteludeks, õppimiseks, strateegiliste plaanide rakendamiseks ning saavutatule hinnangu andmiseks (Nikkanen \& Lyytinen, 2005).

Haridusasutuste meeskondade eripära on see, et nende liikmed peavad sageli tähtsamaks individuaalseid vajadusi, arengut ja saavutusi, mistõttu on meeskonnaliikmete erialane areng pigem individuaalne (Senge et al., 2012). Meeskondlik õppimine toimub siis, kui selle liikmed hakkavad üksteiselt õppima (ibid.). See eeldab omakorda koostöötahet, infovahetust ja suhtlemist, valmisolekut üksteise ärakuulamiseks ja abistamiseks, meeskonnaliikmete mitmekesisust ja kokkusobivust, konfliktide lahendamise võimet ning motiveeriva töökeskkonna loomist (Chang, 1994). Organisatsioon omakorda õpib meeskondliku õppimise kaudu, mis võib toimuda õpilaste, vanemate ja õpetajate suhtluskoostöös (Senge et al., 2012). Sellest lähtudes on oluline tugevdada kooli meeskonnavaimu, kaasates meeskonna liikmeteks ka õpilasi (Nikkanen \& Lyytinen, 2005). 
Kolleegide tugi ja nendevaheline koostöö võimaldavad vahetada kogemusi, analüüsida oma tööd ning leida võimalikke lahendusi ja ennetustegevusi keeruliste olukordade tarbeks. Kolleegidele lisaks võivad tugisüsteemi kuuluda teised isikud, kelle peamine ülesanne on õpetaja või õpilaste toetamine. Koostööd tehakse eelkõige sellistes olukordades, kus õpetaja vajab sotsiaalpedagoogi või koolipsühholoogi tuge ja nõu õpilastega seotud spetsiifiliste probleemide lahendamisel (Schults, 2012). Et suurendada õpetajate oskust kujundada suhteid ning teha koostööd kolleegide, õpilaste ja lastevanematega, võib juhtkond seada üheks strateegiliseks eesmärgiks arendada õpetajate suhtlemisoskust ja -tehnikat, nt individuaalsed ja grupivestlused õpilaste ja vanematega, tagasiside andmine, koosolekute juhatamine (Salumaa, 2007). TALISe uuringust selgus, et õpetajate enesetäiendamise viisidest ongi enim levinud mitteformaalsed arutelud kolleegidega õpetamise arendamise eesmärgil (Loogma et al., 2009). 93\% uuringus osalenud õpetajatest tõi välja dialoogi kui enesetäiendamise ühe vormi, mida oli kasutatud viimase 18 kuu jooksul. Kõige vähem tegid õpetajad vaatluskülastusi teistesse koolidesse ( $28 \%$ õpetajatest) (ibid.). Organisatsiooni kui terviku juhtimise seisukohalt on oluline, et iga õpetaja oskaks hinnata oma arenguvajadusi ja -võimalusi ning tahaks iseseisvalt probleeme lahendada ja edukalt meeskonnas töötada (Marinah \& Omar, 2004).

\section{Süsteemne mõtlemine}

Senge (1990) näeb süsteemses mõtlemises vundamenti, millele õppiv organisatsioon rajatakse, ning osutab, et isiklik meisterlikkus, mõttemudelid, meeskondlik õppimine ja ühine visioon on selle eeldus. Süsteemne mõtlemine võimaldab aru saada süsteemi eri osade toimimisest (Kofman \& Senge, 1993) ning mõista, et organisatsiooni probleemide põhjusteni jõudmiseks on vaja näha osade taga tervikut (Senge, 2006). Õppivas organisatsioonis käsitletakse vigu protsessi loomuliku osana, nendest saadakse kogemusi (Nonaka, 2007).

Süsteemse mõtlemise üks alustalasid on organisatsioonikultuur. Eesti koolijuhtide autonoomia on väga suur. See avaldub õiguses otsustada nii õppetöö sisendite, personalipoliitika, kooli eelarve koostamise ja eelarveraha jaotamise üle kui ka kooli sisekorra, hindamispõhimõtete ja õppeainete sisu üle (Loogma et al., 2009). Samas ei osale direktorid enamasti otseselt õppetöö juhtimises ega toetamises. Eesti koolidirektorite aeg kulub eelkõige administratiivsetele tegevustele ning nad keskenduvad pigem väljundite ehk õpitulemuste kontrollimisele ja koolivälisele aruandlusele. Õppetööd ja selle sisu juhivad eelkõige õppejuhatajad (ibid.). 
Süsteemse mõtlemise tähtsad tegurid - õppetöö hea planeerimise ja ajajuhtimise oskus - on eduka õpetamise olulised eeldused (Koch, 2000). Paraku on õpetajate tegevuse uurimine õppetöö planeerimisel keeruline ülesanne. Ühelt poolt on selle põhjuseks planeerimise kui protsessi mitmekihilisus, teisalt asjaolu, et kõik tunnis toimuv pole planeeritav (Koni \& Krull, 2013). Näiteks esineb olukordi, kus ei teadvustata, et juhtimise muutuste tagajärjed avalduvad viivitusega, millele töötajad võivad reageerida ootamatult ning mis annab soovitule vastupidise tulemuse (Martin, 2005). Õpetaja vajab selliste olukordade tarbeks nii teoreetilisi teadmisi kui ka praktilisi oskusi, sh tegevuste planeerimise ja ajajuhtimise oskuste täiendamist (Salumaa, 2007).

Süsteemset mõtlemist on võimalik õppida ja õpetada ning organisatsioonid saavad edendada kultuuri, mis soodustab süsteemsete mõttemudelite jagamist töötajate vahel (Elenurm, 2004). Kuna süsteemne mõtlemine mõjutab oluliselt organisatsioonilist õppimist ja muutumist (Senge, 2006), on vaja pakkuda töötajatele süsteemse mõtlemise koolitusi, mis aitavad tõhustada nende töösooritust (Bui \& Baruch, 2010).

\section{Empiirilise uurimuse eesmärk ja uurimisküsimused}

Õppiva organisatsiooni põhist juhtimist saab edukalt rakendada haridusasutustes (Roots, Sarv, \& Loogma, 2008). Arusaamine õppiva organisatsiooni distsipliinidest ja nendega arvestamine võimaldavad õpetajal kujuneda ennastjuhtivaks töötajaks ning tõhustada koostoimimist kolleegidega. Varem on õppiva organisatsiooni distsipliinide analüüsimisel lähtutud kolmest tasandist: indiviidi, meeskonna ja organisatsiooni tasandist (Yang, Watkins, \& Marsick, 2004).

Uurimuses analüüsime Senge (1990) õppiva organisatsiooni distsipliine organisatsiooni ja indiviidi tasandil, sest organisatsiooni ülesehitamisel peaks juht lähtuma indiviidist. Uurimisfookuses on põhikooli esimese kooliastme klassiõpetajate arusaamad õppivast organisatsioonist ja selle toimemehhanismidest, sest just klassiõpetaja on tänapäeva Eestis kõige rohkearvulisem õpetajatüüp. Eesmärk on välja selgitada, millised on klassiõpetajate arusaamad Senge õppiva organisatsiooni juhtimise distsipliinidest, et nende alusel luua tõhusalt toimiv juhtimismudel indiviidi ja organisatsiooni tasandil. Uurimuse põhiküsimused on järgmised.

1. Millised õppiva organisatsiooni juhtimise distsipliinid domineerivad klassiõpetajate arusaamades?

2. Millise profiiliga õpetajad eristuvad õppiva organisatsiooni juhtimise distsipliinide analüüsi põhjal? 
3. Millised on erineva profiiliga õpetajate tüüpilised arusaamad tõhusalt toimiva haridusasutuse juhtimisest indiviidi ja organisatsiooni tasandil?

\section{Metoodika}

\section{Valim}

Uuringus osalenud klassiõpetajate andmed kogusime üle-eestilise uurimisprojekti raames, mis keskendus põhikooli efektiivsuse hindamisele (Toomela, 2010). Koolide valikul $(N=28)$ arvestasime valimi representatiivsust: kooli piirkonda ja asukohta (maa- ja linnakool), kooli tüüpi (alg- ja põhikool, gümnaasium). Valimis oli 15 linnakooli ja 13 maakooli. Samuti võtsime arvesse klassikomplektide arvu koolis ja uuritava klassi suurust (suured ja väikesed klassid, liitklassid). Suurimas koolis oli 4 paralleelklassi, igaühes neist rohkem kui 25 õpilast. Väikseimas koolis õppis uuritavas klassis 3 õpilast.

Kõik artiklis analüüsitud klassiõpetajad $(N=47)$ õpetasid põhiaineid (eesti keelt, matemaatikat, loodusõpetust jt) põhikooli esimeses kooliastmes (1.-3. klassis). Õpetajatega tehti intervjuud 3. klassi sügisel. Kuna kahe ópetaja intervjuu salvestamisel oli tekkinud tehniline viga, olid intervjuud nendega jäänud pooleli. Seepärast analüüsime artiklis 45 õpetajaga tehtud intervjuusid. Õpetajate keskmine vanus oli 42 aastat, $S D=7,44(N=41$; $\min =26$ aastat; $\max =58$ aastat), seejuures ei märkinud oma vanust 4 õpetajat. Õpetajate keskmine tööstaaž oli 17,49 aastat, $S D=8,68(N=45$; $\min =1, \max =39$ ).

\section{Intervjuu}

Struktureeritud intervjuuga selgitasime välja, kuidas õpetajad kirjeldavad oma mõttemudeleid ja süsteemset mõtlemist, arusaamu kooli kui organisatsiooni ühisest visioonist ning kuidas nad hindavad enda meisterlikkust ja meeskondlikku õppimist. Struktureeritud intervjuu vormi hindasime sobivaks andmekogumise vahendiks, kuna tahtsime võrrelda õpetajate arusaamu õppiva organisatsiooni juhtimise põhimõtete kohta ja nendest johtudes töötada välja tõhusa haridusasutuse juhtimise mudeli. Intervjuu küsimuste koostamisel toetusime mitmes analoogilises uuringus kasutatud mõõtevahenditele: uuringu Expero4care TC (Pecar, Cervai, \& Kekäle, 2009) küsimustikule, Ellise jt (1997) välja töötatud organisatsioonilise õppimise küsimustikule ning Chiva jt (2007) koostatud õppiva organisatsiooni ja tööga rahulolu küsimustikule. Nendest uuringutest erineb 
meie oma selle poolest, et intervjuu küsimused on paigutatud Senge viie distsipliini mudelisse. Intervjuu kava koosneb 15 põhiküsimusest, mis jaotuvad järgmistesse teemaplokkidesse:

1) õpetaja isiklik meisterlikkus, sh professionaalne kujunemine ja teadmised õpetamisest (Mis on õpetaja tegevuses see, mis tingib õppimise? Opilased ópivad erinevalt. Kirjeldage, kuidas Te olete viimase poole aasta jooksul muutnud oma klassis õppetöö, arvestades mõne õpilasega);

2) õpetaja mõttemudelid ja arusaamad õpetamisest (Millised on olulisimad põhimõtted, millest lähtuvalt siduda õpilase arengutase ja õpetamine?);

3) kooli kui organisatsiooni ühine visioon ja toimimine (Mida tuleks Teie arvates muuta Teie kooli õppetöö korralduses? Opppetegevuste sisus?);

4) meeskondlik õppimine ja koostöö koolis (Kellega Te oma kavasid kooskõlastate? Kellega peaks klassiõpetaja tegema koostööd?);

5) süsteemne mõtlemine indiviidi ja organisatsiooni tasandil (Mis iseloomustab Teie arvates tõeliselt head ópetajat? Miks Teile meeldib töötada just oma koolis? Nimetage kolm olulisimat põhjust).

Intervjuude kestus oli keskmiselt 40 minutit. Intervjuud transkribeerisime sõna-sõnalt täistekstideks, analüüsitud tekstide kogumaht oli $283 \mathrm{lk}$ $(M=6,39, S D=2,89, \min =3,0, \max =16,25)$. Intervjuude tekste analüüsisime suunatud teemaanalüüsi meetodil (Eteläpelto, Vähäsantanen, \& Hökkä, 2015), kasutades peateemadena artikli teooriaosas esitatud Senge (1990) õppiva organisatsiooni kontseptsiooni juhtimise distsipliine: 1) isiklik meisterlikkus, 2) mõttemudelid, 3) ühine visioon, 4) meeskondlik õppimine, 5) süsteemne mõtlemine. Distsipliinide alateemad kujunesid õpetajate intervjuudes sisaldunud kokkulangevuste põhjal. Alateemade leidmiseks lugesime ja kodeerisime intervjuude tekste mitu korda, kõiki intervjuusid analüüsisid teineteisest sõltumatult kaks autorit. Analüüsiühikuks võtsime üksikud laused või lausete kogumid, mis väljendasid mõttelist tervikut. Esialgu oli koode ja/või alateemasid kokku 60, analüüsi käigus vähendasime nende arvu 8-10 koodini teema kohta. Korduva kodeerimise ja arutelude tulemusel valisime välja alateemad, mis pakkusid varasema teooria kõrvale ka uusi arusaamu. Sarnase sisuga koodide ja/või alateemade nimetused ühtlustasime omavahelise arutelu käigus, toetudes teaduskirjandusele. Seejärel täitsime andmetabeli intervjueeritud õpetajate kohta, kasutades dihhotoomset kodeerimist: 1 - tekstis avaldunud (ala)teema; 0 - tekstis puudunud (ala)teema. Igale õpetajale arvutasime alateemade põhjal peateemade koondskoorid $(\max =10)$. Intervjuudes kajastunud pea- ja alateemad on esitatud lisas 1 . 


\section{Statistilise andmeanalüüsi meetodid}

Intervjuude peateemade kohta arvutatud koondskoore kasutasime nii muutuja- kui ka indiviidikesksetes analüüsides. Muutujakesksed analüüsid võimaldasid võrrelda intervjueeritud õpetajaid eeldusel, et valim oli homogeenne, ent väljendumata võisid jääda individuaalsed erinevused (Cohen, Manion, \& Morrison, 2007). Indiviidikesksete analüüside tegemisel toetusime eeldusele, et kogu valim ei pruugi olla homogeenne: selles võivad esineda sarnaste indiviidide alarühmad, kelle vahel on erinevused (Bergman, Magnusson, \& El-Khouri, 2003; Bergman \& Wångby, 2014).

Statistikapaketi SPSS Statistics versiooni 22.0 abil tõime välja kirjeldava statistika. Seejärel analüüsisime erinevusi õpetajate arusaamades óppiva organisatsiooni viie distsipliini alusel, kasutades mitteparameetrilist Friedmani testi. Paariti post-hoc-analüüsi viisime läbi Wilcoxoni testi abil. Et leida kogu valimist profiilirühmad, kelle arusaamad õppiva organisatsiooni distsipliinide kohta erinevad, tegime indiviidikesksed analüüsid statistikapaketti SLEIPNER 2.1 kuuluva CLUSTERi mooduli Wardi meetodiga (Bergman et al., 2003). Valitud klasterlahendust hindasime kolme kriteeriumi alusel: 1) teoreetiline põhjendus, 2) EESSi näitaja, 3) klastrite homogeensus. Analüüsides õpetajate intervjuudes domineerinud õppiva organisatsiooni kontseptsiooni indiviidi ja organisatsiooni tasandi distsipliine, tõime õpetajaprofiile iseloomustavaid tüüpilisi tekstinäiteid intervjuudest.

\section{Tulemused}

\section{Senge õppiva organisatsiooni distsipliinid}

Et selgitada välja klassiõpetajate mõttemudelid ning arusaamad isiklikust meisterlikkusest, organisatsiooni ühisest visioonist, meeskondlikust õppimisest ja süsteemsest mõtlemisest, tõime välja nende viie distsipliini kirjeldava statistika: aritmeetilise keskmise $(M)$, standardhälbe $(S D)$, miinimumtulemuse (min) ja maksimumtulemuse (max) ning keskmise astaku. Kõige kõrgem keskmine skoor oli isiklikul meisterlikkusel ja kõige madalam süsteemsel mõtlemisel. Ometi oli õpetajate arusaamade varieeruvus samade distsipliinide piirides suur, $S D>1,5$ (vt tabel 1). 
Tabel 1. Senge õppiva organisatsiooni distsipliinide kirjeldav statistika

\begin{tabular}{|c|c|c|c|c|c|}
\hline \multirow{2}{*}{$\begin{array}{l}\text { Õppiva organisatsiooni } \\
\text { distsipliinid }\end{array}$} & \multicolumn{5}{|c|}{ Õpetajad $(N=45)$} \\
\hline & $M$ & $S D$ & $\min$ & $\max$ & Keskmine astak \\
\hline \multicolumn{6}{|l|}{ Indiviidi tasandi distsipliinid } \\
\hline Isiklik meisterlikkus (IM) & 4,96 & 1,98 & 1 & 10 & 3,74 \\
\hline Mõttemudelid (MM) & 4,87 & 1,52 & 1 & 8 & 3,90 \\
\hline \multicolumn{6}{|c|}{ Organisatsiooni tasandi distsipliinid } \\
\hline Ühine visioon (ÜV) & 3,49 & 1,16 & 0 & 6 & 2,81 \\
\hline Meeskondlik õppimine (MÕ) & 3,82 & 1,44 & 1 & 7 & 3,04 \\
\hline Süsteemne mõtlemine (SM) & 1,93 & 1,10 & 0 & 6 & 1,50 \\
\hline
\end{tabular}

Järgmise sammuna analüüsisime Senge õppiva organisatsiooni viie distsipliini avaldumist õpetajate intervjuudes, kasutades mitteparameetrilist Friedmani testi. Selgus, et rühma keskmiste tulemuste tasemel avaldusid opetajate arusaamades statistiliselt olulised erinevused, $\chi^{2}=71,71, d f=4$, $p<0,001$. Paariti post-hoc-võrdlusest Wilcoxoni testiga ilmnes, et indiviidi ja organisatsiooni tasandi distsipliinide vahel esinesid erinevused. Isikliku meisterlikkuse keskmine skoor oli statistiliselt oluliselt kõrgem kui organisatsiooni tasandi distsipliinide skoorid: süsteemne mõtlemine, $Z=-5,35$, $p<0,001$; ühine visioon, $Z=-4,09, p<0,001$; meeskondlik óppimine, $Z=-2,66, p=0,008$. Samasuunalised statistiliselt olulised erinevused ilmnesid ka õpetajate mõttemudeli ja organisatsiooni tasandi kolme distsipliini vahel. Nimelt, oluliselt rohkem kirjeldasid õpetajad oma mõttemudelit võrreldes distsipliinidega süsteemne mõtlemine, $Z=-5,69, p<0,001$; ühine visioon, $Z=-3,76, p<0,001$; meeskondlik oppimine, $Z=-3,03, p=0,002$. Lisaks ilmnesid erinevused organisatsiooni tasandi distsipliinide võrdluses - arusaamu meeskondlikust óppimisest ja ühisest visioonist väljendati rohkem kui arusaamu süsteemsest mõtlemisest, vastavalt $Z=-4,79$, $p<0,001$ ja $Z=-4,35, p<0,001$.

\section{Õpetajate profiilid Senge õppiva organisatsiooni distsipliinide järgi}

Eespool selgus, et õpetajate arusaamad õppiva organisatsiooni distsipliinidest erinesid rühma keskmise tulemuse põhjal. Et selgitada välja süstemaatilised erinevused õpetajate arusaamades, kasutasime indiviidikeskseid analüüse (Bergman et al., 2003). Kõigepealt leidsime RESIDUE mooduli abil erindid. Kuus õpetajat, kelle õppiva organisatsiooni distsipliinide skoorid 
olid teiste õpetajatega võrreldes kas erandlikult kõrged või madalad, jätsime järgnevatest analüüsidest välja. Seejärel tegime hierarhilise klasteranalüüsi (CLUSTERi mooduli Wardi meetod), kus 39 õpetajat liigitusid klastritesse õppiva organisatsiooni viie distsipliini standardiseeritud tulemuste põhjal. Analüüsi tulemusel jõudsime seitsmeklastrilise lahenduseni, arvestades mudeli teoreetilist põhjendust, EESSi näitajat $(=64,53)$ ja klastrite homogeensust $(<1,0)$ (vt tabel 2).

Tabel 2. Õpetajate profiile kirjeldavad näitajad

\begin{tabular}{l|c|c|c|c|c|c|c|c|c|c|c}
\hline \multirow{2}{*}{ Klaster } & \multirow{2}{*}{$N=39$} & \multicolumn{2}{|c|}{ IM } & \multicolumn{2}{c|}{ MM } & \multicolumn{2}{c|}{ ÜV } & \multicolumn{2}{c|}{ MÕ } & \multicolumn{2}{c}{ SM } \\
\cline { 3 - 11 } & & $M$ & $S D$ & $M$ & $S D$ & $M$ & $S D$ & $M$ & $S D$ & $M$ & $S D$ \\
\hline KL1 & 7 & 3,43 & 0,79 & 4,86 & 0,69 & 2,43 & 0,53 & 4,0 & 1,73 & 2,71 & 0,49 \\
\hline KL2 & 7 & 7,0 & 0,82 & 4,43 & 1,27 & 3,57 & 0,53 & 3,14 & 0,9 & 2,43 & 0,53 \\
\hline KL3 & 5 & 6,8 & 0,84 & 6,2 & 0,45 & 3,40 & 0,55 & 5,0 & 0,71 & 1,60 & 0,89 \\
\hline KL4 & 5 & 5,60 & 1,52 & 6,60 & 0,55 & 2,80 & 0,84 & 2,40 & 1,14 & 1,20 & 0,45 \\
\hline KL5 & 7 & 4,43 & 0,79 & 4,14 & 0,9 & 5,14 & 0,69 & 2,71 & 0,95 & 1,29 & 0,76 \\
\hline KL6 & 4 & 4,25 & 0,96 & 3,25 & 1,5 & 3,75 & 0,5 & 5,5 & 0,58 & 2,0 & 0,0 \\
\hline KL7 & 4 & 2,0 & 0,82 & 4,75 & 0,96 & 3,25 & 0,5 & 5,0 & 0,0 & 1,0 & 0,0 \\
\hline
\end{tabular}

Märkus. KL - klaster, IM - isiklik meisterlikkus, MM - mõttemudelid, ÜV - ühine visioon, MÕ - meeskondlik õppimine, SM - süsteemne mõtlemine.

Õpetajate profiilide tõlgendamisel kasutasime muutuja standardiseeritud skoori: $Z>1,0$ - kõrge tase, $Z<1,0$ - madal tase, $Z$ vahemikus $-1,0$ kuni 1,0 - keskmine tase. Kõigi seitsme profiilirühma õpetajate arusaamade skoorid õppiva organisatsiooni distsipliinide korral olid teiste rühmade õpetajatega võrreldes kas oluliselt kõrgemad või madalamad (vt joonis 2 ja tabel 3). 


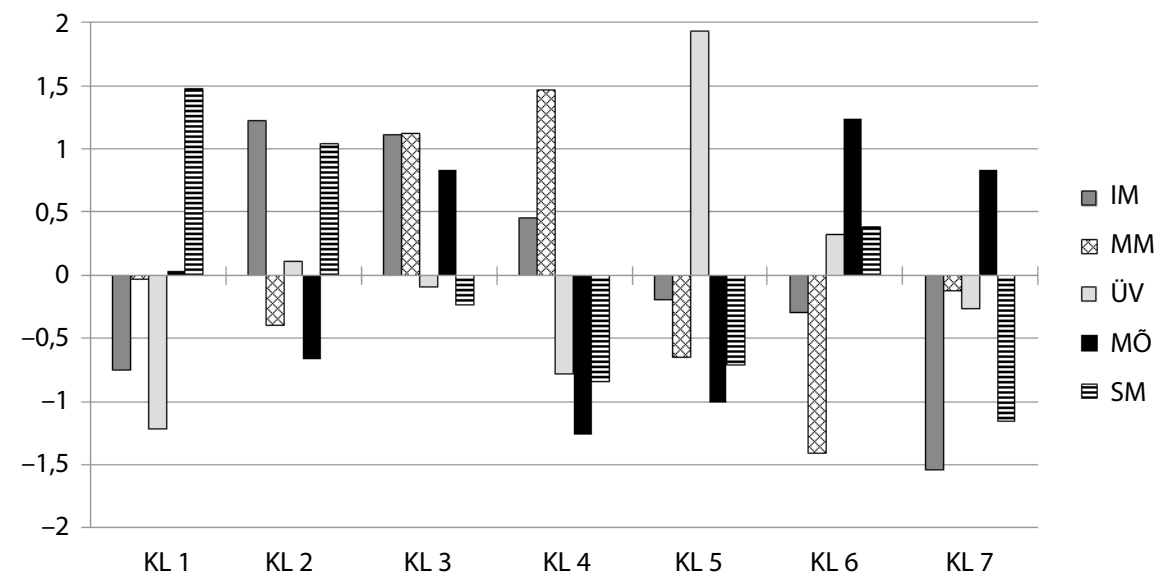

Joonis 2. Senge õppiva organisatsiooni distsipliinide standardiseeritud skoorid õpetajate profiilirühmades. $\mathrm{KL}$ - klaster, IM - isiklik meisterlikkus, MM - mõttemudelid, ÜV - ühine visioon, MÕ - meeskondlik õppimine, SM - süsteemne mõtlemine

Tabel 3. Õpetajate profiilide kirjeldused standardiseeritud skooride järgi

\begin{tabular}{|c|c|c|c|c|c|c|c|c|c|c|c|}
\hline \multirow{2}{*}{$\begin{array}{l}\text { Klas- } \\
\text { ter }\end{array}$} & \multirow{2}{*}{$\begin{array}{c}\text { Profiili } \\
\text { kirjeldus }\end{array}$} & \multicolumn{2}{|c|}{ IM } & \multicolumn{2}{|c|}{ MM } & \multicolumn{2}{|c|}{ ÜV } & \multicolumn{2}{|c|}{ MÕ } & \multicolumn{2}{|c|}{ SM } \\
\hline & & $M$ & TG & $M$ & TG & $M$ & TG & $M$ & TG & $M$ & $T G$ \\
\hline KL1 & $S M_{\text {körge }}$ & $-0,75$ & $\begin{array}{l}\text { kesk- } \\
\text { mine }\end{array}$ & $-0,03$ & $\begin{array}{l}\text { kesk- } \\
\text { mine }\end{array}$ & $-1,21$ & madal & 0,03 & $\begin{array}{l}\text { kesk- } \\
\text { mine }\end{array}$ & 1,48 & kõrge \\
\hline KL2 & $I_{\text {körge }}$ & 1,22 & kõrge & 0,4 & $\begin{array}{l}\text { kesk- } \\
\text { mine }\end{array}$ & $-0,11$ & $\begin{array}{l}\text { kesk- } \\
\text { mine }\end{array}$ & $-0,67$ & $\begin{array}{l}\text { kesk- } \\
\text { mine }\end{array}$ & 1,05 & kõrge \\
\hline KL3 & $\begin{array}{l}\text { Indi- } \\
\text { viid }_{\text {körge }}\end{array}$ & 1,11 & kõrge & 1,13 & kõrge & $-0,09$ & $\begin{array}{l}\text { kesk- } \\
\text { mine }\end{array}$ & 0,84 & $\begin{array}{l}\text { kesk- } \\
\text { mine }\end{array}$ & $-0,23$ & $\begin{array}{l}\text { kesk- } \\
\text { mine }\end{array}$ \\
\hline KL4 & $M_{\text {körge }}$ & 0,45 & $\begin{array}{l}\text { kesk- } \\
\text { mine }\end{array}$ & 1,47 & kõrge & $-0,79$ & $\begin{array}{l}\text { kesk- } \\
\text { mine }\end{array}$ & $-1,26$ & madal & $-0,84$ & $\begin{array}{l}\text { kesk- } \\
\text { mine }\end{array}$ \\
\hline KL5 & ÜV $V_{\text {körge }}$ & $-0,2$ & $\begin{array}{l}\text { kesk- } \\
\text { mine }\end{array}$ & $-0,64$ & $\begin{array}{l}\text { kesk- } \\
\text { mine }\end{array}$ & 1,93 & kõrge & $-1,01$ & madal & $-0,7$ & $\begin{array}{l}\text { kesk- } \\
\text { mine }\end{array}$ \\
\hline KL6 & $\begin{array}{l}\text { Sega- } \\
\text { profiil_1 }\end{array}$ & $-0,3$ & $\begin{array}{l}\text { kesk- } \\
\text { mine }\end{array}$ & $-1,41$ & madal & 0,32 & $\begin{array}{l}\text { kesk- } \\
\text { mine }\end{array}$ & 1,24 & kõrge & 0,39 & $\begin{array}{l}\text { kesk- } \\
\text { mine }\end{array}$ \\
\hline KL7 & $\begin{array}{l}\text { Sega- } \\
\text { profiil_2 }\end{array}$ & $-1,54$ & madal & $-0,12$ & $\begin{array}{l}\text { kesk- } \\
\text { mine }\end{array}$ & $-0,26$ & $\begin{array}{l}\text { kesk- } \\
\text { mine }\end{array}$ & 0,84 & $\begin{array}{l}\text { kesk- } \\
\text { mine }\end{array}$ & $-1,15$ & madal \\
\hline
\end{tabular}

Märkus. TG - tasemegrupp, IM - isiklik meisterlikkus, MM - mõttemudelid, ÜV - ühine visioon, MÕ - meeskondlik õppimine, SM - süsteemne mõtlemine. 
Õpetajate jaotus profiilirühmades oli üsna võrdne. Ligi 18\% õpetajaid liigitus profiilirühmadesse $\mathrm{SM}_{\text {kõrge }}$ ja $\mathrm{UV}_{\text {kõrge, }}$ mida iseloomustas kahe organisatsioonitasandi distsipliini märkimisväärselt kõrge tase. Nii oli profiilirühmal $\mathrm{SM}_{\text {kõrge }}$ kõrge süsteemse mõtlemise skoor $(Z=1,43)$ ja rühmal ÜV $V_{\text {kõrge }}$ kõrge ühise visiooni skoor $(Z=1,93)$. Kolme rühma õpetajaid Indiviid $_{\text {körge }}, \mathrm{MM}_{\text {körge }}, \mathrm{IM}_{\text {körge }}$ - iseloomustas seevastu indiviidi tasandi ühe või mõlema distsipliini kõrge tase. Nende rühmade õpetajad pidasid oluliseks eelkõige isiklikku meisterlikkust ja kirjeldasid oma mõttemudeleid mitmekesiselt.

Lisaks eristus kaks neljaliikmelist õpetajate rühma, nn segaprofiili, kellel ei ilmnenud selget erinevust indiviidi ja organisatsiooni tasandi distsipliinide vahel. Seejuures iseloomustas rühma Segaprofiil_1 õpetajaid suur kõikumine mõttemudelite ja meeskondliku óppimise skoori vahel (Z-skoor: -1,41 kuni 1,24). Rühmale Segaprofiil_2 oli omane kõigi distsipliinide avaldumine kas keskmisel või madalal tasemel.

\section{Õppiva haridusasutuse juhtimine indiviidi ja organisatsiooni tasandil}

Et saada detailsemat ülevaadet klassiõpetajate kirjeldustes avaldunud õppiva organisatsiooni distsipliinidest, analüüsisime erinevaid õpetajaprofiile iseloomustavaid tüüpilisi tekstinäiteid nende intervjuudest. Selgus, et õpetajate arusaamad haridusasutuse juhtimise põhimõtetest olid erinevad, vastustes domineerisid pigem kas indiviidi või organisatsiooni tasandi distsipliinide kirjeldused (vt tabel 4 ja lisa 1).

Esimesse tüüpi kuulusid profiilirühmade $\mathrm{IM}_{\text {kõrge, }}$ Indiviid kôrge, $\mathrm{MM}_{\text {kôrge }}$ õpetajad, kes kirjeldasid põhjalikumalt indiviidi tasandile iseloomulikke komponente: oma tegevust, käitumist ja valikuid õppeprotsessis ehk isiklikku meisterlikkust. Samuti mõtestasid nad sügavamalt oma rolli koolis.

Teise tüübina eristusid õpetajad, kes keskendusid oma vastustes peamiselt ühisele visioonile või meeskondlikule õppimisele organisatsiooni tasandil (ÜV kôrge, Segaprofiil_1). Need õpetajad oskasid täpselt ja põhjalikult selgitada, milline on hästi toimiv koolijuhtimise ja õpetajate tunnustamise süsteem ning milline on juhi roll koolis. Selle tüübi õpetajad väärtustasid üldiselt seda, et otsused koolis langetatakse kooskõlastatult, neil on hea meeskond ja mikrokliima ning koolijuhid ja kolleegid peavad oluliseks õpetaja professionaalset arengut. 
Tabel 4. Iseloomulikke näiteid õpetajate intervjuudest

\begin{tabular}{|c|c|c|}
\hline Tasand & $\begin{array}{l}\text { Tüübi } \\
\text { kirjeldus }\end{array}$ & Näiteid intervjuudest \\
\hline $\begin{array}{l}\text { Indiviidi } \\
\text { tasand }\end{array}$ & $\begin{array}{l}\mathrm{IM}_{\text {körge }} \\
\text { Indiviid }_{\text {kôrge }} \\
\text { MM }_{\text {körge }}\end{array}$ & $\begin{array}{l}\text { Õpetaja 1: „Tulebki siin nagu leida igale lapsele sobiv } \\
\text { lähenemisviis. Meetodid, mis paneksid nad õppima, et iga } \\
\text { õpilane tunneb, et ikka tema saab ka hakkama ja tema ka oskab.” } \\
\text { Õpetaja 2: „Kui ma tundi annan, siis ma arvestan sellega, milline } \\
\text { on nagu selline vastuvõtt. [... ]. Järjest enam me suuname lapsi } \\
\text { teadlikule õppimisele, et nad saaksid aru, miks nad õpivad, mida } \\
\text { nad õpivad, ... mille poolest see neile vajalik on ja mida võib } \\
\text { saavutada tulevikus, ... et millisel erialal millised teadmised on } \\
\text { vajalikud.” } \\
\text { Õpetaja 3: „Õpetajale on muidugi selles mõttes koormav ja raske, } \\
\text { et sa pead ju parandusõppe tunni materjalid kõik ise kokku } \\
\text { panema ja otsima, mitte kusagil ei ole ühtegi parandusõppe } \\
\text { õpikut.” }\end{array}$ \\
\hline $\begin{array}{l}\text { Orga- } \\
\text { nisat- } \\
\text { siooni } \\
\text { tasand }\end{array}$ & $\begin{array}{l}\text { ÜV } V_{\text {körge }} \\
\text { Sega- } \\
\text { profiil_1 }\end{array}$ & $\begin{array}{l}\text { Õpetaja 4: „Väike maakool ja rahaliselt ei ole võimalik kindlasti } \\
\text { motiveerida. Lootsin, et saan arvuti, kuna oleme e-koolis, paraku } \\
\text { loosiga tõmmati, ei jätkunud kõikidele õpetajatele arvuteid.” } \\
\text { Õpetaja 5: „Ükskõik mis teemadel on vaja abi paluda, suhelda, } \\
\text { siis alati aidatakse. Kooliväline tegevus on ka hea, õppepäevad, } \\
\text { võtavad kõik osa - terve kool. Ei ole nii, et ainete kaupa oleks } \\
\text { ära jaotatud, et ajalooõpetaja tegeleb ajalooga, et algklassid on } \\
\text { omaette. Kõik on nagu võrdselt.” } \\
\text { Õpetaja 6: „Teen oma töökavad pooleks aastaks. [...] Meie } \\
\text { kooskõlastame õppealajuhatajaga ja aeg-ajalt teeme koostööd } \\
\text { paralleelklassi õpetajaga.” } \\
\text { Õpetaja 7: „Meil on hästi eluterve õhkkond, meil on hästi vahva } \\
\text { kollektiiv.” }\end{array}$ \\
\hline $\begin{array}{l}\text { Süs- } \\
\text { teemne } \\
\text { mõtle- } \\
\text { mine }\end{array}$ & $\mathrm{SM}_{\text {körge }}$ & $\begin{array}{l}\text { Õpetaja 8: „Heasoovlikkus, sõbralikkus, oskus kõiki lapsi } \\
\text { näha võib-olla ja kõiki mõista. [...] lga laps ju ootab, et teda } \\
\text { märgatakse, et tema saavutusi tunnustatakse, nii nagu me isegi. } \\
\text { Niisugust õpetajat peakski hindama. See ongi hea õpetaja. Ja } \\
\text { loomulikult see oma aine tundmine.” } \\
\text { Õpetaja 9: „Õpetamine on mitmekülgne laste arendamine võib- } \\
\text { olla ja praegu räägitakse väga palju üldse, et tuleb õpetada } \\
\text { õppima, et see on hirmus oluline.” } \\
\text { Õpetaja 10: ,See, kui ma ei peaks muretsema, kas, kust ja } \\
\text { mismoodi ma neid vahendeid saan, et ma ei peaks öösiti neid } \\
\text { joonistama ise, et ma ei peaks muretsema, kas ma saan seda } \\
\text { õpikut kasutada, mida ma tahaksin kasutada. Seekord ma näiteks } \\
\text { ei saa, mul on ühe kirjastuse töövihik, teise kirjastuse õpik. Et ma } \\
\text { saaksin vabalt nagu tunda ennast, see on eriti oluline. Ega palk } \\
\text { ei ole vähem oluline, siis ma võib-olla ei käiks kuskilt kõrvalt ka } \\
\text { tööd tegemas.” }\end{array}$ \\
\hline
\end{tabular}


Kolmandasse tüüpi paigutusid õpetajad (profiilirühm $\mathrm{SM}_{\text {kõrge), kelle }}$ vastustes peegeldus võime näha ja mõista nähtuste ja olukordade seoseid (nt õppeainete integreerimine) ning põhjuse ja tagajärje suhet (nt otsused teadmiste põhjal). Need õpetajad mõtestasid oma koolis ja Eesti hariduselus toimunud muutuste tagajärgi (nt tagasiside arvestamist muutuste elluviimisel). Nad pidasid oluliseks õpilaste ettevalmistust elus toimetulekuks, toetudes ise õppekava suunistele ja õpetamisteooriatele ning väärtustades enda professionaalset arengut. Nende hinnangul on õpetaja isikliku arengu ja kooli edenemise seisukohalt tähtis õppida tagasisidest ja vigadest ning langetada kaalutletud otsuseid.

\section{Arutelu}

Uuring selgitas välja Eesti klassiõpetajate arusaamad Senge õppiva organisatsiooni juhtimise distsipliinidest organisatsiooni ja indiviidi tasandil. Kasutades rühma- ja indiviidikeskseid analüüse, tuvastasime erinevused nii kogu valimi keskmiste tulemuste tasemel kui ka erineva profiiliga õpetajate vahel. Ilmnes, et klassiõpetajad kirjeldasid põhjalikumalt õppiva organisatsiooni distsipliine indiviidi tasandil, st oma isiklikku meisterlikkust ja mõttemudeleid. Seevastu organisatsiooni tasandi distsipliinid ühine visioon, meeskondlik õppimine ja süsteemne mõtlemine - avaldusid õpetajate arusaamades tagasihoidlikumalt. Uuringu tulemuste põhjal saab välja pakkuda tõhusalt toimiva haridusasutuse juhtimise mudeli.

\section{Õpetajate arusaamad õppiva organisatsiooni juhtimisest}

Esiteks uurisime klassiõpetajate arusaamu organisatsiooni toimimisest Senge (1990) õppiva organisatsiooni juhtimise viie distsipliini alusel. Indiviidi ja organisatsiooni tasandi distsipliinide vahel ilmnesid erinevused. Kõige detailsemalt kirjeldasid õpetajad oma isiklikku meisterlikkust, mis seostub nende igapäevatöö ja õpetamisoskustega ning sellega, kuidas õpetaja õppeprotsessi juhib, õpilastega suhtleb ja neid motiveerib (Åkerlind, 2003). Seejuures on olulisel kohal õppeprotsessis tehtavad valikud ja oskus neid õpilastele selgitada - see on seotud õpetaja mõttemudelite, kogemuste ja professionaalsusega (Guskey, 2002). Klassikliima ja korra hoidmine tunnis nõuavad autoriteeti, õpetamise struktureerimist ja klassi ohjamise oskusi. Suhted õpilastega viitavad õpikeskkonna kvaliteedile, mis eeldab õpetajalt häid sotsiaalseid oskusi, empaatiat ja austust õpilaste vastu (Loogma et al., 2009). Ka Åkerlind (2003) käsitleb õpetamisega seotud arusaamade põhjal õpetamist kui info edastamist, heade suhete loomist 
(olulised on õppijate rahulolu ja õppesisu edastamine) ning õppijate ja nende õppimise toetamist.

Organisatsiooni tasandi distsipliinidega võrreldes kirjeldasid õpetajad rohkem oma mõttemudelit, väljendades arusaamu ja hinnanguid ning andes ülevaate enda õpetamise põhimõtetest, väärtushinnangutest ja professionaalsest kujunemisest. Oma mõttemudelite teadvustamist ja väljendamist peetakse eduka meeskondliku õppimise eelduseks (Senge, 1990). Isiklike mõttemudelite mõistmine ja uurimine annab võimaluse neid muuta ning tegelda samal ajal sügavamate uskumustega, mis hõlmavad nii ainealaseid ja pedagoogilisi teadmisi kui ka enesetõhusust (Khader, 2012; Korthagen \& Vasalos, 2005). Samas on see üsna keeruline, sest mõttemudelid kujutavad endast kinnistunud kogemusi ja arusaamu inimese mälus. Oskus hinnata ennast kõrvalseisja pilguga on oluline professionaalse arengu kontekstis.

Oluliselt vähem kui isiklikku meisterlikkust ja mõttemudeleid kirjeldasid klassiópetajad oma kooli ühist visiooni ja meeskondliku õppimise süsteemi. Neid võib pidada pigem organisatsiooni tasandit iseloomustavateks distsipliinideks, mistõttu võis nende kirjeldamine osutuda õpetajatele keerulisemaks kui indiviidi tasandi distsipliinide esitamine. Õppiva organisatsiooni juht peab olema õpetaja, disainer ja muutuste tegija (Senge, 1990). On leitud, et koolijuhtimine, mis keskendub ühisele visioonile ja meeskondlikule õppimisele, aitab kaasa kooli arengule ja suurendab selle konkurentsivõimet (Montuori, 2000). Kooli ühine visioon ja ühiskonna areng seavad õpetajate enesetäiendamisele uusi nõudeid - uuendamist ja arendamist vajavad nii õppetegevusega seotud teadmised, praktilised oskused, ajaplaneerimine kui ka meeskonnatöö oskused (nt suhtlemine, konfliktide lahendamine) (Chang, 1994; Loogma et al., 2009; Saadoja, 2013). Euroopas korraldatud uuringust selgus, et tõhusalt juhitud koolides olid õpetajad motiveeritud osalema täiendusõppes, mis on suunatud kooli juhtimisele ja kooli mikrokliima paranemisele (Pont et al., 2009).

Süsteemset mõtlemist iseloomustavaid komponente esines klassiõpetajate intervjuudes oluliselt vähem kui teiste õppiva organisatsiooni distsipliinide omi. Senge (2006) hinnangul on süsteemne mõtleja õppivas organisatsioonis indiviid, kes mõistab organisatsiooni toimimist. See omakorda soodustab muutusi ja takistavate tegurite märkamist. Ilma süsteemse mõtlemiseta on keeruline, kui mitte võimatu, töötada välja organisatsioonile sobiv juhtimisstrateegia (Bui \& Baruch, 2010). 


\section{Erinevused õpetajate profiilides}

Analüüsides süstemaatilisi erinevusi õpetajate arusaamades organisatsiooni juhtimisest intervjuudes esinenud peateemade järgi, eristus seitse profiilirühma. Õpetajate jaotus rühmades oli üsna võrdne (4-7 õpetajat). Kaks profiilirühma (Indiviid kôrge $_{\text {ja }} \mathrm{IM}_{\text {körge }}$ ) eristusid teistest kahe distsipliini avaldumise kõrge taseme poolest. Nii oli profiili Indiviid kõrge $_{\text {õpeta- }}$ jatele iseloomulik mõlema indiviidi tasandi distsipliini - isikliku meisterlikkuse ja mõttemudelite - kirjeldamise kõrge tase. Profiilirühma $\mathrm{IM}_{\text {kõrge }}$ õpetajaid iseloomustas peale suure isikliku meisterlikkuse ka süsteemse mõtlemise keskmisest veidi kõrgem tase. Nende komponentide rohke avaldumise põhjuseks võib olla see, et õpetamine on alati seotud õpetaja professionaalsusega (Harrison, 2013) ning enda tegevuste kirjeldamine võis olla õpetajatele lihtsam. Õpetajate professionaalne areng nõuab ka selliste uute rollide omandamist, mis arendavad uusi oskusi ja on omakorda tihedalt seotud organisatsiooni arenguga (Anderson et al., 2006; Cheng \& Tsui, 1999; Loogma et al., 2009). Koolijuhil on õpetajate professionaalse arengu soodustamisel tähtis roll ning sellest lähtuvalt tuleks planeerida ka õpetajate enesetäiendamist (Pont et al., 2009). Lisaks eristus rühm õpetajaid $\left(\mathrm{MM}_{\mathrm{korge}}\right)$, kelle arusaamu iseloomustas mõttemudelite kõrge tase ning tendents kirjeldada põhjalikumalt oma isiklikku meisterlikkust. Oskus väljendada sõnades oma arusaamu ja hoiakuid õpetamise suhtes, on üsna haruldane. On leitud, et koos eneseanalüüsioskuste arendamisega paraneb oskus teadvustada oma mõttemudeleid (Meglino \& Ravlin, 1998). Uskumused on aga kompleksne süsteem, mis hõlmab enesetõhusust, erialaseid teadmisi ja organisatsioonikultuuri mõjusid (Khader, 2012), mistõttu nende uurimine ja väljaselgitamine on üsna keeruline.

Profiilirühmades $\ddot{U} V_{\text {kõrge }}$ ja $\mathrm{SM}_{\text {kôrge }}$ domineeris organisatsiooni tasandi ühe distsipliini - ühise visiooni või süsteemse mõtlemise - väga kõrge tase, seevastu teiste distsipliinide kirjeldused nendes rühmades olid väga madalal tasemel $(Z \leq 0,3)$. Kooli ühise visioonini jõudmiseks tuleb läheneda õpetamisele, õppimisele ja õppekorraldusele uuel viisil, seostades eri õppeaineid kooli õppekavas (Kukk, 2010; Kuusk, 2008; Pont et al., 2009). See omakorda võimaldab arendada süsteemset mõtlemist. Haridusasutuse ühine visioon kujundatakse õpetajate visioonide ja eesmärkide alusel (Elenurm, 2004; Scholtes, 1998) ning õpetajate tegevuse sidumisel kooli õppekava tasandil (Kukk, 2010; Kuusk, 2008). Juhtide ülesanne on jagada visiooni ja ehitada üles óppiv organisatsioon (Senge, 1990).

Praeguses uurimuses eristus ka kaks väiksemat nn segaprofiili rühma, mida iseloomustab suur erinevus indiviidi ja organisatsiooni tasandi 
distsipliinide vahel. Nende rühmade õpetajate põhjal saab oletada, et konkreetsete koolide juhtimises võis puududa dünaamika või ei tajunud õpetajad oma rolli ja täpseid ülesandeid organisatsioonis (vt Rogers, 2002). Nimelt ei ole Crevani jt (2010) hinnangul haridusasutuse juhtimine seotud ainult juhi individuaalsete teadmiste ja oskustega, vaid see on osa erinevatest protsessidest, praktikatest ja suhtluskoostööst, mis moodustavad terviksüsteemi. Oluline on, et juhid mõistaksid lineaarsete põhjuse ja tagajärje seoste kõrval mehhanisme, mille tõttu võivad nende läbimõtlemata otsused olemasolevaid probleeme süvendada. Näiteks püütakse kõrvaldada probleemi väliseid ilminguid, kasutades selleks kiire mõjuga lühiajalisi lahendusi, kuid probleemi sisuline lahendamine lükkub edasi ning ei olegi lõpuks organisatsioonile jõukohane (Elenurm, 2004). Samuti on õpetajate jaoks oluline teadmine, et nende töömeetodid on sobivad ning kooli juhtkond, hoolekogu ja kolleegid toetavad neid (Pijl, 2010).

Niisiis, uurimuses avaldunud profiilirühmade üsna suur arv ja õpetajate võrdne jaotus profiilirühmades annavad põhjust oletuseks, et Eesti haridusorganisatsioonide juhtimises valitseb variatiivsus - puudub dominantne juhtimismudel, mida eelistatakse paljudes koolides. Haridusorganisatsiooni juhtimine tänapäeval eeldab peale isikliku meisterlikkuse ka Senge õppiva organisatsiooni ülejäänud distsipliinide rakendamist. Oluline on ühine visioon, mille elluviimist toetab meeskondlik õppimine, aga ka organisatsiooni kui tervikut haarav süsteemne mõtlemine (Senge, 1990). Selline mõtteviis kujuneb välja teatud isiklike hoiakute ja väärtushinnangute baasil.

\section{Tõhusa haridusasutuse juhtimise mudel}

Senge õppiva organisatsiooni käsitlus võimaldab parandada organisatsiooni võimekust (Appelbaum \& Goransson, 1997). Sellest teadmisest lähtusime ka tõhusa haridusasutuse juhtimise mudeli väljatöötamisel. Koolijuhtidelt oodatakse üha enam mentorluse korraldamist ja juhtimist ning õpetajate enesetäiendamise edendamist, mis toimuks osaliselt meeskondliku õppimisena. Eesmärk on suurendada organisatsiooni toimimise tõhusust ja arengut (Pont et al., 2009). Meeskondlike tegevuste juhtimine eeldab õpetaja valmisolekut täita meeskonnas eri rolle, sh liidri rolli (Kasl, Marsick, \& Deshant, 1997). Kui koostööd nähakse pigem juhi antud kohustusena kui reaalsest vajadusest ajendatud tegevusena, on selle tõhusus piiratud (Pont et al., 2009).

Nagu iga süsteem, koosneb ka haridusasutus eri komponentidest (nt struktuur, liikmed), ja olenemata sellest, et igal komponendil on oma 
funktsioon, peaksid need olema omavahel kooskõlas (Appelbaum \& Goransson, 1997; Nevis, DiBella, \& Gould, 1995; Stata, 1989). Tõhusa haridusasutuse juhtimise mudeli loomiseks analüüsisime klassiõpetajate arusaamu Senge õppiva organisatsiooni juhtimise distsipliinidest, lähtudes haridusasutusele sobivast järjekorrast (Senge et al., 2003). Senge esitab juhtimise põhimõtted õppiva organisatsiooni viie distsipliini kaudu, kuid tema käsitluses on kõik distsipliinid võrdväärsed. Praeguste uurimistulemuste põhjal saab väita, et haridusasutuse juhtimine ei ole juhtimise distsipliinide lõikes lineaarne ega hierarhiline, vaid parimate tulemuste saavutamiseks peab see olema horisontaalne ja laiapõhjaline (vt joonis 3).

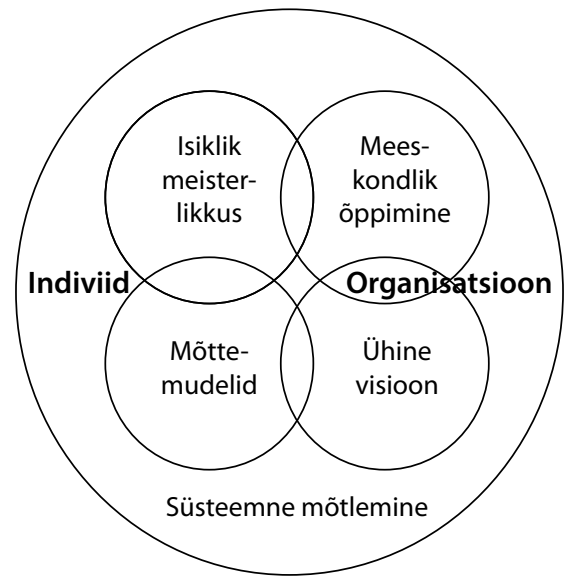

Joonis 3. Õppiva haridusasutuse tõhusa juhtimise mudel organisatsiooni ja indiviidi tasandi alusel

Praegust uurimistulemust saab võrrelda Yangi jt (2004) omaga, mille korral lähtuti õppiva organisatsiooni distsipliinide kirjeldamisel kolmest tasandist, milleks on organisatsioon, meeskond ja indiviid. Uurimistulemuste põhjal konstrueeritud tõhusa haridusasutuse juhtimise mudelis eristus samuti kolm tasandit - indiviidi, organisatsiooni ja süsteemse mõtlemise tasand -, mis paigutusid hierarhiliselt: süsteemne mõtlemine kui kõige komplekssem distsipliin hõlmas nii indiviidi kui ka organisatsiooni tasandit (vt ka Kiedrowski, 2006).

\section{Piirangud ja järeldused}

Uurimuses ilmnesid mõned piirangud, mida tuleb arvestada haridusasutuse juhtimise mudeli rakendamisel. Esiteks, andmekogumise vahendina kasutasime struktureeritud intervjuud, mis ei taga uuritavatele täielikku 
anonüümsust ning võib mõjutada vastamist. Samas ei tundnud intervjueerija uuritavaid varem ja kohtus nendega vaid intervjuu tegemise eesmärgil. Teiseks, variatiivsus ópetajate valimis oli üsna suur, mida väljendas uurimuses avaldunud profiilirühmade arv. Samuti ei kasutanud me analüüsides õpetajate taustaandmeid ega koolikeskkonnaga seotud tegureid.

Uurimuse tugevuseks võib pidada intervjueeritud õpetajate suurt arvu, mis võimaldas edasi arendada Senge õppiva organisatsiooni juhtimise mudelit haridusasutuse jaoks. Lisaks kodeerisid kaks autorit kõiki intervjuusid ning kasutasid nii muutuja- kui ka indiviidikeskseid analüüse, suurendades seeläbi uurimuse valiidsust. See võimaldas saada uuritavate kohta infot, mis ainult muutujapõhiste analüüside puhul võinuks jääda väljendumata (Bergman et al., 2003; Bergman \& Wångby, 2014). Tehtud uuringu põhjal saab teha olulisi järeldusi ja anda praktilisi soovitusi.

1. Õpetamine ja juhtimine nõuavad paindlikkust ning valmisolekut katsetada uut (Crainer, 1998). Enamik koolijuhte või juhikandidaate on õpetaja taustaga, mistõttu tööle asuvad direktorid ei pruugi olla haridusjuhtidena kompetentsed. Meie uuringus osalenud õpetajate arusaamad organisatsiooni juhtimise kohta näitavad, et koolijuhtidel puuduvad sageli teadmised personalitööst, ajaplaneerimisest, samuti finantsjuhtimise oskused ning pädevused tööks väljaspool kooli. Kuna need oskused kuuluvad vajalike juhtimisoskuste hulka (Pont et al., 2009), tuleb neid arendada.

2. Õpetajate hinnangul kalduvad juhid väärtustama pigem individuaalset kogemust, kuid ei tunneta kollektiivse ja korporatiivse kogemuse tähtsust. Uuringust ilmnes, et mitmete koolide juhtimises puudub dünaamika või ei taju õpetajad selgelt oma rolli ja ülesandeid koolis. Arvestades meie uuringu ja TALISe tulemusi (Loogma et al., 2009), tuleb toetada õpetajate professionaalset arengut, pakkudes neile enesetäiendamise võimalusi, mis on kooskõlas organisatsiooni vajadustega.

3. Toetudes õpetajate kirjeldustele õpetamise põhimõtetest, väärtushinnangutest ja professionaalsest kujunemisest ning süsteemse mõtlemise alustele ja tõhusalt toimiva haridusasutuse juhtimise mudelile, tuleks õpetajakoolituse põhi- ja täiendusõppes teha mõned sisulised muudatused: lõimida üksikdistsipliine, kujundada väärtustel põhinevaid mõttemudeleid, arendada õpetajate juhtimispädevusi ja pakkuda kogemuspõhise juhtimise koolitusi.

4. Ilmnes, et õpetajate arusaamad ja hoiakud erinevad olulisel määral Senge süsteemsest käsitlusest. Ühest küljest vajavad õpetajad professionaalse arengu edendamiseks praktilisi näpunäiteid, teisalt on haridusasutuste meeskondade eripäraks liikmete individuaalne erialane areng. 
Sellest lähtudes tuleb välja töötada täienduskoolituse programmid, mis toetavad ühisel visioonil ja sarnastel mõttemudelitel põhinevate koolimeeskondade ja õpivõrgustike arengut. See loob eeldused, mis võimaldavad haridusasutustel kujuneda õppivateks organisatsioonideks.

5. Selgus, et haridusasutuse juhtimine on protsesside, praktikate ja suhtluse kogum - õpetajate jaoks on oluline teadmine, et nende töömeetodid on sobivad. Et koolijuhid mõistaksid õpetajaid paremini, oskaksid neid toetada ja tunneksid tänapäevaseid õpetamismeetodeid, on tähtis, et nad teeksid õppetööd vähemalt mõned tunnid nädalas, nagu see on tavaks mõnedes Euroopa riikides (nt Austria, Belgia, Prantsusmaa, Soome, Inglismaa).

\section{Tänusõnad}

Uurimust on toetanud Eesti Teadusagentuur, grant nr IUT03-03 „Indiviidi akadeemiline ja isiksuslik areng formaalharidussüsteemis".

\section{Kasutatud kirjandus}

Ahonen, M., \& Kaseorg, M. (2007). Õppiva organisatsiooni kontseptsiooni rakendamine mikro- ja väikeettevõtete näitel. Eesti sotsiaalteaduste VII aastakonverents, 23.-24.11.07, Tartu. Külastatud aadressil http://oeiax4.nw.eenet.ee/esso4/20404.pdf.

Åkerlind, G. S. (2003). Growing and developing as a university teacher - Variation in meaning. Studies in Higher Education, 28(4), 375-390.

doi: http://dx.doi.org/10.1080/0307507032000122242

Allen, D. (1996). Why learning organizations work. Edinburgh: Edinburg University. Anderson, D. F., Bryson, J. M., Richardson, G. P., Ackermann, F., Eden, C., \& Finn, C. B. (2006). Integrating modes of systems thinking into strategic planning. Education and practice: Thinking persons' institute approach. Journal of Public Affairs Education, 12(3), 265-293.

Retrieved from http://www.albany.edu/ gpr/JPAE06.pdf.

Appelbaum, S. H., \& Goransson, L. (1997). Transformational and adaptive learning within the learning organization: A framework for research and application. The Learning Organization, 4(3), 115-128. doi: http://dx.doi.org/10.1108/09696479710182803

Bergman, L. R., Magnusson, D., \& El-Khouri, B. M. (2003). Studying individual development in an interindividual context: A person-oriented approach. Mahwah, London: Lawrence Erlbaum Associates.

Bergman, L. R., \& Wångby, M. (2014). Indiviidile suunatud käsitlusviis: lühike teoreetiline ja praktiline juhend. Eesti Haridusteaduste Ajakiri, 2(1), 7-28.

doi: http://dx.doi.org/10.12697/eha.2014.2.1.02 
Bui, H., \& Baruch, Y. (2010). Creating learning organizations: A systems perspective. The Learning Organization, 17(3), 208-227. doi: http://dx.doi.org/10.1108/09696471011034919

Chang, R. Y. (1994). Success through teamwork: A practical guide to international team dynamics. Irvine, CA: Chang Associates.

Cheng, Y. C., \& Tsui, K. T. (1999). Multimodels of teacher effectiveness: Implications for research. The Journal of Educational Research, 92(3), 141-150. doi: http://dx.doi.org/10.1080/00220679909597589

Chiva, R., Alegre, J., \& Lapiedra, R. (2007). Measuring organizational learning capability among the workforce. International Journal of Manpower, 28(3/4), 224-242.

Cohen, L., Manion, L., \& Morrison, K. (2007). Research methods in education (6th ed.). London, New York: Routledge.

Crainer, S. (1998). Key management ideas: The thinkers that changed the management world (3rd ed.). London: Pitman Publishing.

Crevani, L., Lindgren, M., \& Packendorff, J. (2010). Leadership, not leaders: On the study of leadership as practices and interactions. Scandinavian Journal of Management, 26(1), 77-86. doi: http://dx.doi.org/10.1016/j.scaman.2009.12.003

Darling-Hammond, L. (2000). Teacher quality and student achievement: A review of state policy evidence. Education Policy Analysis Archives, 8(1), 1-44. doi: http://dx.doi.org/10.14507/epaa.v8n1.2000

DiBella, J. A. (1995). Developing learning organizations: A matter of perspective. Academy of Management Best Papers Proceedings, 287-290. doi: http://dx.doi.org/10.5465/AMBPP.1995.17536560

Elenurm, T. (2004). Senge salapärane teooria. Director, veebruar. Külastatud aadressil http://www.director.ee/senge-salaprane-teooria/.

Eley, M. G. (2006). Teachers' conceptions of teaching, and the making of specific decisions in planning to teach. Higher Education, 51(2), 191-214. doi: http://dx.doi.org/10.1007/s10734-004-6382-9

Ellis, S., Globerson, S., \& Parsons, B. (1997). Performance improvement in a project environment: A survey analysis. Project Management Institute Conference, Chicago October 1997.

Eteläpelto, A., Vähäsantanen, K., \& Hökkä, P. (2015). How do novice teachers in Finland perceive their professional agency? Teachers and Teaching, 21(6), 660680. doi: http://dx.doi.org/10.1080/13540602.2015.1044327

Fullan, M., Galluzzo, G., Morris, P., \& Watson, N. (1998). The rise and stall of teacher education reform. Washington, D.C.: American Associate of Colleges of Teacher Education.

Garvin, D. A. (1993). Building a learning organization. Harvard Business Review, 71(4), 78-91.

Griego, O. V., Geroy, G. D., \& Wright, P. C. (2000). Predictors of learning organizations: A human resource development practitioner's perspective. The Learning Organization, 7(1), 5-12. doi: http://dx.doi.org/10.1108/09696470010313632

Guskey, T. R. (2002). Professional development and teacher change. Teachers and Teaching: Theory and Practice, 8(3), 381-391.

doi: http://dx.doi.org/10.1080/135406002100000512 
Harrison, C. (2013). Collaborative action research as a tool for generating formative feedback on teachers' classroom assessment practice: The KREST project. Teachers and Teaching: Theory and Practice, 19(2), 202-213. doi: http://dx.doi.org/10.1080/13540602.2013.741839

Karm, M., \& Remmik, M. (2013). Algajate õppejõudude õpetamisarusaamad fotointervjuude põhjal. Eesti Haridusteaduste Ajakiri, 1, 124-155. doi: http://dx.doi.org/10.12697/eha.2013.1.07

Kasl, E., Marsick, V. J., \& Dechant, K. (1997). Teams as learners: A research-based model of team learning. The Journal of Applied Behavioral Science, 33(2), 227-246. doi: http://dx.doi.org/10.1177/0021886397332010

Kets de Vries, M. (2002). Juhtimise müstika. Tallinn: Pegasus.

Khader, F. R. (2012). Teachers' pedagogical beliefs and actual classroom practices in social studies instruction. American International Journal of Contemporary Research, 2(1), 73-92.

Kiedrowski, P. J. (2006). Quantitative assessment of a Senge learning organization intervention. The Learning Organization, 13(4), 369-383. doi: http://dx.doi.org/10.1108/09696470610667742

Killion, J., \& Roy, P. (2009). Becoming a learning school. Oxford, OH: National Staff Development Council.

Kim, D. H. (1993). The link between individual and organizational learning. Sloan Management Review, 35(1), 37-50.

Retrieved from http://ejournal.narotama.ac.id/files/The\%20Link\%20Between\%20 Individual\%20and\%20Organizational\%20Learning.pdf.

Koch, R. (2000). 80:20 printsiip: Kuidas saavutada vähemaga rohkem. Tallinn: TEA.

Kofman, F., \& Senge, P. M. (1993). Communities of commitment: The heart of the learning organization. Organizational Dynamics, 22(2), 5-23.

doi: http://dx.doi.org/10.1016/0090-2616(93)90050-B

Koni, I., \& Krull, E. (2013). Õppetöö planeerimisoskuste modelleerimine ning hindamine algajatel ja kogenud õpetajatel. E. Krull, Ä. Leijen, M. Lepik, J. Mikk, L. Talts, \& T. Õu (toim.), Õpetajate professionaalne areng ja selle toetamine. Projekti „Õpetajate professionaalne areng ja selle toetamine" tulemused ópetajakoolituse teenistuses (lk 186-206). Tartu: Eesti Ülikoolide Kirjastus.

Korthagen, F., \& Vasalos, A. (2005). Levels in reflection: Core reflection as a means to enhance professional growth. Teachers and Teaching: Theory and Practice, 11(1), 47-71. doi: http://dx.doi.org/10.1080/1354060042000337093

Kukk, A. (2010). Õppekava eesmärkide saavutamine üleminekul lasteasutusest kooli ning I kooliastmes õpetajate hinnanguil (doktoritöö). Tallinna Ülikool, Tallinn. Külastatud aadressil http://www.digar.ee/arhiiv/nlib-digar:62301.

Kuusk, T. (2008). Opppekava integratsiooni võimalusi. Külastatud aadressil http://www.curriculum.ut.ee/sites/default/files/sh/juhend_6ppekava_integratsioon.pdf.

Lampert, M. (1997). Teaching about thinking and thinking about teaching, revisited. In V. Richardson (Ed.), Constructivist teacher education: Building a world of new understandings (pp. 84-107). London: The Falmer Press.

Loogma, K., Ruus, V-R., Talts, L., \& Poom-Valickis, K. (2009). Oppetaja professionaalsus ning tõhusama õpetamis- ja õppimiskeskkonna loomine. OECD rahvusvahelise ópetamise ja óppimise uuringu TALIS tulemused. Tallinn: Tallinna Ülikooli haridusuuringute keskus. 
Marinah, A., \& Omar, A. K. (2004). School as a learning organization: A reality or merely myth? Paper presented at the 3rd Asian Conference of the Academy of HRD, 20.-23. November, Seoul, Korea.

Martin, S. (2005). Sustainability, systems thinking and professional practice. Systemic Practice and Action Research, 18(2), 163-171. doi: http://dx.doi.org/10.1007/s11213-005-4156-7

Meglino, B. M., \& Ravlin, E. C. (1998). Individual values in organizations: Concepts, controversies, and research. Journal of Management, 24(3), 351-389. doi: http://dx.doi.org/10.1177/014920639802400304

Montuori, L. A. (2000). Organizational longevity - Integrating systems thinking, learning and conceptual complexity. Journal of Organizational Change Management, 13(1), 61-73. doi: http://dx.doi.org/10.1108/09534810010310249

Mumford, A. (1992). Individual and organizational learning: The pursuit of change. Management Decision, 30(6). doi: http://dx.doi.org/10.1108/EUM0000000000110

Nevis, E. C., DiBella, A. J., \& Gould, J. M. (1995). Understanding organizations as learning systems. Sloan Management Review, Winter, 73-85.

Nikkanen, P., \& Lyytinen, H. K. (2005). Õppiv kool ja enesehindamine. Töövahendeid haridusasutuste arendamiseks. El Paradiso.

Nonaka, I. (2007). The knowledge creating company. Harvard Business Review, JulyAugust. Retrieved from https://hbr.org/2007/07/the-knowledge-creating-company.

Pajares, M. F. (1992). Teachers' beliefs and educational research: Cleaning up a messy construct. Review of Educational Research, 62(3), 307-332. doi: http://dx.doi.org/10.3102/00346543062003307

Pecar, Z., Cervai, S., \& Kekäle, T. (2009). Developing an European quality assessment tool for schools. Total Quality Management Journal, 21(3), 284-296. doi: http://dx.doi.org/10.1108/17542730910953059

Pedler, M., Bourgoyne, J., \& Boydell, T. (1991). The learning company: A strategy of sustainable development. London: McGraw-Hill.

Pijl, S. J. (2010). Preparing teachers for inclusive education: Some reflections from the Netherlands. Journal of Research in Special Educational Needs, 10(1), 197-201. doi: http://dx.doi.org/10.1111/j.1471-3802.2010.01165.x

Pont, B., Nusche, D., \& Moorman, H. (2009). Koolijuhtimise täiustamine. 1. osa: poliitika ja praktika. OECD, Riiklik Eksami- ja Kvalifikatsioonikeskus (eestikeelne väljaanne). Külastatud aadressil https://www.hm.ee/sites/default/files/koolijuhtimise_taiustamine.pdf.

Rogers, B. (2002). Teacher leadership and behaviour management. London: Paul Chapman Publishing.

Roots, H. (2004). Õppiv organisatsioon ja juhtimise uus paradigma. Euroopalik valitsemine: Eesti väljakutsed ja valikud. Acta Politica, 1, 147-162.

Roots, H., Sarv, E-S., \& Loogma, K. (2008). Õppeasutus kui õppiv organisatsioon. M. Kitsing (toim.), Ôppeasutuse sisehindamine (lk 5-43). Tartu: Haridus- ja Teadusministeerium.

Saadoja, K. (2013). Õpetajate ühendused ja võrgustike koostöö. Innove uudiskiri, 18, september. Külastatud aadressil http://www.innove.ee/et/yldharidus/esfprogrammid/yldhariduse-pedagoogide-kvalifikatsiooni-tostmine/uudiskiri/ uudiskiri-18/opetajate-yhendused-ja-vorgustike-koostoo. 
Salumaa, T. (2007). Representatsioonid organisatsioonikultuuridest Eesti kooli pedagoogidel muutuste protsessis (doktoritöö). Tallinna Ülikool, Tallinn.

Sanders, W. L., \& Rivers, J. C. (1996). Cumulative and residual effects of teachers on future student academic achievement (Research Progress Report). Knoxville, University of Tennessee Value-Added Research and Assessment Center.

Scholtes, P. R. (1998). The leader's handbook. Making things happen, getting things done. New York, NY: McGraw-Hill.

Schults, A. (2012). Pedagoogide tugisüsteem. Tartu: Tartu Linnavalitsuse haridusosakond.

Senge, P. M. (1990). The fifth discipline: The art and practice of the learning organization. New York, NY: Doubleday.

Senge, P. M. (2006). The fifth discipline: The art \& practice of the learning organisation. London: Random House Business Books.

Senge, P. M., Cambron-McCabe, N., Lucas, T., Smith, B., Dutton, J., \& Kleiner, A. (2012). Schools that learn. New York, NY: CrownBusiness.

Senge, P. M., Kleiner, A., Roberts, C., Ross, R. B, \& Smith, B. J. (2003). Viie distsipliini käsiraamat: strateegiad ja vahendid óppiva organisatsiooni loomiseks. Tartu: Fontese Kirjastus.

Siimon, A., \& Vadi, M. (1999). Organisatsioon ja organisatsioonikultuur. Tartu: Tartu Ülikooli majandusteaduskond.

Stata, R. (1989). Organizational learning: The key to management innovation. Sloan Management Review, Spring, 63-74.

Toomela, A. (Ed.). (2010). Systemic person-oriented study of child development in early primary school. Frankfurt am Main etc.: Peter Lang.

Torff, B., \& Sessions, D. N. (2009). Principals' perceptions of the causes of teacher ineffectiveness in different secondary subject. Teacher Education Quarterly, 36(3), 127-148.

Torokoff, M. (2008). Patterns of learning organisation - Estonian experience (Doctoral dissertation). Tartu Ülikool, Tartu.

Retrieved from http://dspace.ut.ee/handle/10062/6379.

Võgotski, L. (2014). Mõtlemine ja kõne. Tartu: Ilmamaa.

Wenglinsky, H. (2002). How schools matter: The link between teacher classroom practices and student academic performance. Education Policy Analysis Archives, 10(12). Retrieved from http://epaa.asu.edu/ojs/article/view/291/417.

Yang, B., Watkins, K. E., \& Marsick, V. J. (2004). The construct of the learning organization: Dimensions, measurement, and validation. Human Resource Development Quarterly, 15(1), 31-55. doi: http://dx.doi.org/10.1002/hrdq.1086 
Lisa 1. Intervjuudes avaldunud teemad ja alateemad esinemissageduse järjekorras

\begin{tabular}{|c|c|c|c|c|}
\hline $\begin{array}{c}\text { Isiklik } \\
\text { meisterlikkus }\end{array}$ & $\begin{array}{l}\text { Mõtte- } \\
\text { mudelid }\end{array}$ & $\begin{array}{c}\text { Meeskondlik } \\
\text { opppimine }\end{array}$ & $\begin{array}{c}\text { Ühine } \\
\text { visioon }\end{array}$ & $\begin{array}{l}\text { Süsteemne } \\
\text { mõtlemine }\end{array}$ \\
\hline $\begin{array}{l}\text { Õppetöö } \\
\text { diferentseeri- } \\
\text { mine }\end{array}$ & $\begin{array}{l}\text { Teadmiste } \\
\text { andmine ja } \\
\text { kinnistamine }\end{array}$ & Kolleeg & $\begin{array}{l}\text { Tunnusta- } \\
\text { mine }\end{array}$ & \begin{tabular}{|l} 
Õppekava ja \\
-materjalide \\
järgimine
\end{tabular} \\
\hline $\begin{array}{l}\text { Õpetaja } \\
\text { sisemine } \\
\text { motivatsioon }\end{array}$ & $\begin{array}{l}\text { Ea- ja } \\
\text { võimetekohane } \\
\text { õpetamine }\end{array}$ & $\begin{array}{l}\text { Sotsiaal- } \\
\text { pedagoog ja/ } \\
\text { või paran- } \\
\text { dusõpetaja }\end{array}$ & $\begin{array}{l}\text { Organisat- } \\
\text { siooni- } \\
\text { kultuur }\end{array}$ & $\begin{array}{l}\text { Õpetamis- } \\
\text { teooriate } \\
\text { kasutamine }\end{array}$ \\
\hline $\begin{array}{l}\text { Isiksuslikud } \\
\text { omadused }\end{array}$ & $\begin{array}{l}\text { Kognitiivse } \\
\text { arengu } \\
\text { arvestamine }\end{array}$ & $\begin{array}{l}\text { Logopeed ja } \\
\text { eripedagoog }\end{array}$ & $\begin{array}{l}\text { Hea } \\
\text { mikrokliima }\end{array}$ & $\begin{array}{l}\text { Ettevalmistus } \\
\text { elus } \\
\text { toimetulekuks }\end{array}$ \\
\hline $\begin{array}{l}\text { Professionaalne } \\
\text { areng }\end{array}$ & $\begin{array}{l}\text { Mõtlemisoskuste } \\
\text { arendamine }\end{array}$ & Lapsevanem & $\begin{array}{l}\text { Juhi } \\
\text { kontroll }\end{array}$ & $\begin{array}{l}\text { Teadmistel } \\
\text { põhinev } \\
\text { otsustamine }\end{array}$ \\
\hline $\begin{array}{l}\text { Oppemeetodite } \\
\text { variatiivsus }\end{array}$ & Huvi äratamine & Psühholoog & $\begin{array}{l}\text { Õppe- } \\
\text { korralduse } \\
\text { muutused }\end{array}$ & $\begin{array}{l}\text { Õppeainete } \\
\text { integreerimine }\end{array}$ \\
\hline $\begin{array}{l}\text { Pädevuste } \\
\text { andmine }\end{array}$ & $\begin{array}{l}\text { Õpioskuste ja } \\
\text {-harjumuse } \\
\text { arendamine }\end{array}$ & $\begin{array}{l}\text { Juhtkond } \\
\text { (õppe- } \\
\text { juhataja) }\end{array}$ & $\begin{array}{l}\text { Tegevuste } \\
\text { koos- } \\
\text { kõlastamine }\end{array}$ & Ajajuhtimine \\
\hline $\begin{array}{l}\text { Suhtlemis- } \\
\text { oskused }\end{array}$ & $\begin{array}{l}\text { Õpilase holistlik } \\
\text { arendamine }\end{array}$ & $\begin{array}{l}\text { Iseendale } \\
\text { lootmine }\end{array}$ & $\begin{array}{l}\text { Õpetaja } \\
\text { professio- } \\
\text { naalse aren- } \\
\text { gu toetamine }\end{array}$ & $\begin{array}{l}\text { Tagasiside } \\
\text { arvestamine }\end{array}$ \\
\hline $\begin{array}{l}\text { Toetumine } \\
\text { isiklikule } \\
\text { kogemusele }\end{array}$ & $\begin{array}{l}\text { Õpilase } \\
\text { juhendamine }\end{array}$ & Ôpilased & $\begin{array}{l}\text { Ühise } \\
\text { visiooni } \\
\text { puudumine }\end{array}$ & \\
\hline $\begin{array}{l}\text { Õpilase } \\
\text { motiveerimine }\end{array}$ & $\begin{array}{l}\text { Väärtus- } \\
\text { hinnangute } \\
\text { ja käitumise } \\
\text { kujundamine }\end{array}$ & & & \\
\hline $\begin{array}{l}\text { Õpitu } \\
\text { mõistmine ja } \\
\text { rakendamine }\end{array}$ & & & & \\
\hline $\begin{array}{l}\text { Õpetamis- } \\
\text { oskuste } \\
\text { arendamine }\end{array}$ & & & & \\
\hline $\begin{array}{l}\text { Tagasi- } \\
\text { sidestamine }\end{array}$ & & & & \\
\hline $\begin{array}{l}\text { Eeskuju } \\
\text { järgimine }\end{array}$ & & & & \\
\hline
\end{tabular}




\title{
Perceptions of primary school teachers on the disciplines related to the learning of organisation leadership
}

\author{
Krista Uibu $^{\text {al }}$, Merike Kaseorg ${ }^{b}$, Toomas Kink ${ }^{c}$ \\ a Institute of Education, University of Tartu \\ ${ }^{b}$ Faculty of Economics and Business Administration, University of Tartu \\ c Tartu Raatuse School
}

\section{Summary}

\section{Introduction}

The increase in the recognition of the learning organisation theory since 1990s has substantially changed the approach to the organisation management - social capital and organisation culture have been prioritised. Peter Senge (1990) defines learning organisations as "the organizations where people continually expand their capacity to create the results they truly desire, where new and expansive patterns of thinking are nurtured, where collective aspirations are set free, and where people are continually learning to see the whole together". According to Senge the leadership of a learning organisation is based on five disciplines: personal mastery, mental models, building shared vision, team learning and systems thinking. On the basis of their focus the disciplines can be divided into two categories: the personal level (personal mastery and mental models) and the organisational level (shared vision and team learning). Systems thinking involves both levels. When managing an educational institution it may be difficult to draw clear borders between different disciplines as they are closely connected and influence each other.

The ability to recognise opportunities and to be responsible for the choices made is a precondition for personal mastery. It entails personal vision on, and notion of, the organisational context. A person who has attained personal mastery has an adequate perception of the actual state of affairs and focuses on his/her personal image. This affects the knowledge and actions of teachers during the learning process (Darling-Hammond, 2000; Fullan et al., 1998; Marinah \& Omar, 2004). The success of organisations depends, inter alia, on the mental models, decisions and behaviour of its members (Mumford, 1992). Mental models influence directly what

1 Institute of Education, University of Tartu, Salme 1a, 50103 Tartu, Estonia; krista.uibu@ut.ee 
humans do, and how they do it (Vygotski, 2014). Understanding of each other's mental models and expressing one's own view is essential from the perspective of team learning.

Shared vision that triggers changes forms the basis for the comprehensive development of an organisation (Nikkanen \& Lyytinen, 2005). Shared vision is built upon personal visions of all the employees within the organisation. Common elements have to be found in personal visions so that employees can see the common path and principles of operation that help to implement the vision (Schults, 2012). The headmaster of a school has to keep the targets and vision of the organisation in sight, point out the strengths and competencies of the team, and draw attention to the aspects that need to be improved (Nikkanen \& Lyytinen, 2005; Pont et al., 2009). Team learning can be achieved only if team members start to learn from each other (Senge et al., 2012). This requires readiness for co-operation, communication, diversity and consistency among the members of the team and the ability to resolve conflicts, as well as the existence of motivating micro-climate (Chang, 1994).

Systems thinking is the foundation upon which the learning organisation is built (Senge, 1990). Systems thinking can be learnt and taught and organisations can promote the culture that facilitates the distribution of systems mental models between employees (Martin, 2005). The aim of this study is to find out which disciplines of leadership of a learning organisation are prevailing in the teachers' perception, in order to develop a leadership model of an effective educational institution at personal and organisational levels. On the basis of Senge's theory on the learning organisation, the following three study questions were formulated:

1. Which disciplines of learning organisation prevail in the descriptions given by primary school teachers?

2. What are the profiles of teachers on the basis of disciplines of the learning organisation?

3. What are the typical perceptions of teachers with different profiles on the personal and organisational level disciplines of an effective educational institution?

\section{Method}

Within the framework of the study 47 primary school teachers from 28 Estonian schools who taught basic subjects from Grade 1 to Grade 3 were interviewed. The sample was formed on the basis of the location, type of 
school and the size of classes. This article analyses the interviews carried out with 45 teachers. The interview consisted of 15 basic questions that were divided into the following thematic blocks:

1. The professionalism of a teacher and his/her knowledge of teaching;

2. Perceptions and mental models of a teacher;

3. Functioning of a school as an organisation and a shared vision;

4. Co-operation and team learning at school;

5. Systems thinking at personal and organisational level.

The interviews conducted with the teachers were fully transcribed and analysed by the method of targeted thematic analysis. Senge's (1990) disciplines of the leadership of learning organisation were used as the main theme, sentences or sets of sentences that expressed a conceptual whole were used as analytic units. By using analyses that were focused either on teams or individuals, the differences between the average results of teams and between the teachers with different profiles were identified (Bergman et al., 2003; Cohen et al., 2007).

\section{Major results and discussion}

It appeared that primary school teachers described more thoroughly the personal level disciplines of the learning organisation (personal mastery and mental models). The organisational level disciplines (shared vision, team learning and systems thinking) were expressed in a more modest manner than in the teachers' perception. Teachers were most detailed in their descriptions about their personal mastery that was connected to the teachers' everyday work and teaching skills, and how they control the learning process, communicate with pupils and motivate them (Åkerlind, 2003). Teachers described more frequently also their mental models. Being aware of these models allows the alteration of them and dealing with more profound beliefs that include self-efficacy, specialist knowledge and cultural influences (Khader, 2012). Both, the personal mastery as well as mental models appeared substantially more frequently in teachers' interviews than the disciplines related to the organisational level (systems thinking, shared vision and team learning). Differences appeared also in the organisational level disciplines: notions on team learning and shared vision were more commonly expressed than systems thinking. The frequency of mentioning systems thinking was especially low, which may be related to the lack of the relevant theoretical knowledge of teachers (Khader, 2012). However, the shared vision within an organisation and team learning are important for 
supporting operations of individual employees in the organisation (Kim, 1993).

The analysis of systematic differences between teachers' perception related to the organisational management that was carried out on the basis of the themes contained in their interviews revealed seven teacher profile groups (each contained from four to seven teachers). The teachers of two groups were characterised by the high level of personal mastery and mental models or high level of personal mastery and systems thinking. This may be explained by the fact that teaching has always been connected with teacher's professionalism (Harrison, 2013) and a headmaster has an important influence on the facilitation of teachers' professional development. It is important to co-ordinate teachers' professional development at school (Pont et al., 2009). The teachers of one of the profile groups were characterised by the high frequency of describing mental models. The success of organisations is dependent on mental models, decisions and behaviour of the members of these organisations (Mumford, 1992).

Two profile groups stood out describing very thoroughly everything related to the organisational level, but did not speak much about personal level. One of these groups was characterised by the shared vision of their organisation and the second group was characterised by a very high level of systems thinking. The description frequency of other leadership disciplines was very low. The building of shared vision in an educational institution is based on teachers' personal visions and objectives (Elenurm, 2004; Scholtes, 1998), as well as the integration of different actions of teachers at the level of the school's curriculum (Kukk, 2010; Kuusk, 2008). The integration of a curriculum is necessary for ensuring that teachers, as well as students, are able to link different competencies. That lays the foundations for the development of systems thinking at the school.

Two smaller profile groups were characterised by a great difference between personal and organisational level disciplines. It is possible to assume, on the basis of teachers belonging to these groups, that the management of certain schools may lack dynamics or maybe the teachers did not understand their exact role and tasks within the organisation (Rogers, 2002). In order to ensure the satisfaction of teachers it is important to offer them a stable organisation and development opportunities (Salumaa, 2007). In a learning organisation it is important to focus on the development of activities that ensure the quality of the learning process (Garvin, 1993; Nikkanen \& Lyytinen, 2005; Pedler et al., 1991; Senge, 1990). Teachers, also need to know that their working methods are appropriate, and 
they should expect support from the management staff and the board of trustees of a school, as well as from their colleagues (Pijl, 2010).

Thus, the relatively large number of profile groups revealed in the study, and the equal distribution of teachers among the profile groups allows the presumption that the management of Estonian educational institution is variable - no leadership model that is preferred in many schools prevails over others. Managing a modern educational institution requires, in addition to personal mastery, also the use of the rest of the disciplines of Senge's learning organisation. In order to create an effective management model of an educational institution the perception of primary school teachers were analysed on the basis of Senge's disciplines of leadership of a learning organisation (Senge et al., 2003). Senge presents the management principles of five disciplines of a learning organisation and according to him all disciplines are equal. On the basis of the results of this study it is possible to argue that the management of an educational institution cannot be linear by the management disciplines, but it should be hierarchical (see the Figure below).

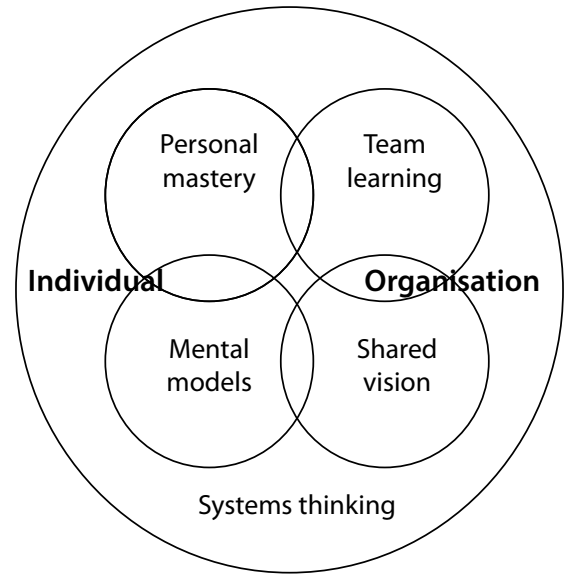

Figure. The model of effective management of an educational institution by organisational and personal levels

The results of the study can be compared with the approach of Yang and others (2004) where the disciplines of a learning organisation were described through three levels: an organisation, team and individual. The model of effective management of an educational institution created on the basis of the results of this study, a three level model stood out, but the setup of the levels was different: individual, organisation and the systems thinking as the most comprehensive discipline covering both of them. 


\section{Acknowledgements}

This work was supported by the Estonian Research Council Grant No IUT03-03 (Academic and personal development of an individual in the system of formal education).

Keywords: learning organisation, disciplines of leadership, teacher's profile, targeted thematic analysis 